\title{
Natural Phenolic Compounds for the Control of Oxidation, Bacterial Spoilage, and Foodborne Pathogens in Meat
}

\author{
Aphrodite I. Kalogianni ${ }^{1}{ }^{1}$, Thomai Lazou ${ }^{2}$, Ioannis Bossis ${ }^{1}$ and Athanasios I. Gelasakis ${ }^{1, * \mathbb{C}}$ \\ 1 Laboratory of Anatomy and Physiology of Farm Animals, Department of Animal Science, \\ Agricultural University of Athens (AUA), Iera Odos 75 str., 11855 Athens, Greece; afrokalo@aua.gr (A.I.K.); \\ bossisi@aua.gr (I.B.) \\ 2 Laboratory of Hygiene of Foods of Animal Origin-Veterinary Public Health, School of Veterinary Medicine, \\ Faculty of Health Sciences, Aristotle University of Thessaloniki, 54124 Thessaloniki, Greece; \\ tlazou@vet.auth.gr \\ * Correspondence: gelasakis@aua.gr
}

Received: 26 April 2020; Accepted: 12 June 2020; Published: 16 June 2020

\begin{abstract}
Alternative technologies for long-term preservation, quality assurance, and safety of meat are continuously pursued by the food industry to satisfy the demands of modern consumers for nutritious and healthy meat-based products. Naturally occurring phenolic compounds are considered promising substances by the meat industry for their antioxidant and antimicrobial properties, while consumers seem to embrace them for their claimed health benefits. Despite the numerous in vitro and in situ studies demonstrating their beneficial effects against meat oxidation, spoilage, and foodborne pathogens, wide application and commercialization has not been yet achieved. Major obstacles are still the scarcity of legislative framework, the large variety of meat-based products and targeted pathogens, the limited number of case-specific application protocols and the questionable universal efficiency of the applied ones. The objectives of the present review are (i) to summarize the current knowledge about the applications of naturally occurring phenols in meat and meat-based products, emphasizing the mechanisms, determinants, and spectrum of their antioxidant and antimicrobial activity; (ii) to present state-of-the-art technologies utilized for the application of phenolic compounds in meat systems; and (iii) to discuss relevant regulation, limitations, perspectives, and future challenges for their mass industrial use.
\end{abstract}

Keywords: natural phenolic compounds; antioxidant activity; antimicrobial activity; meat; meat-based products; foodborne pathogens; spoilage

\section{Introduction}

During the last 70 years, an increased demand for foods of animal origin and especially meat and meat products has been observed worldwide. This has resulted in the intensification of livestock production and the development of globalized logistics and complex transboundary trade of meat products. In addition, evolution of nutritional habits, changes in lifestyle, and other societal, religious, and monetary factors have reshaped the meat industry and its future growth and direction. Despite the continuous emergence of new food trends, meat and meat products will remain a significant source of animal-derived protein and essential amino acids in human nutrition [1].

To meet consumer demands for fresh meat and adhere to food safety regulations, extensive supply chains have been developed worldwide utilizing cold chain logistics. Despite the universal adoption of basic food cold chains, alternative technologies for long-term preservation, quality assurance and meat safety are continuously pursued. Meat and its products are ideal substrates for the growth and 
propagation of spoilage microorganisms and common foodborne pathogens, rendering them as high-risk perishable foods with potential public health implications [2,3]. More than $20 \%$ of worldwide meat production, which is equivalent to 75 million slaughtered cows, is lost or wasted along the food supply chain due to spoilage [4]. In monetary terms, meat losses account for $\sim 4 \%$ of total food losses and cost about $\$ 150$ billion USD, representing more than $20 \%$ of the global economic cost due to food losses [5].

Meat contamination with pathogens may originate from any point across the "farm to fork" continuum, which includes animal farming, transportation, slaughtering, processing, packaging, distribution, and meal preparation in the household environment $[2,6]$. The basic pillar for meat hygiene is the control measures to eliminate or reduce pathogenic or spoilage microorganisms in farms, slaughterhouses, and meat processing plants. These measures are integrated in the hazard analysis and critical control point (HACCP) plan, which is a legislative requirement in developed countries [3,7-9]. Currently, hygiene and preservation methods utilized by the meat industry include (i) heat treatment (e.g., scalding of carcasses, pasteurization, water, and steam boiling treatment); (ii) refrigeration (e.g., chilling, freezing, blast chilling, superchilling); (iii) high hydrostatic pressure (HHP); (iv) packaging (vacuum, modified atmosphere, and active packaging); (v) ionizing radiation; (vi) chemical preservatives (carbon dioxide, chlorine dioxide, ozone, lactoferrin, organic acids (e.g., lactic and citric acid), salts (e.g., nitrates, sodium lactate, sodium chloride, sodium benzoate, trisodium phosphate, potassium sorbate)), and bioactive compounds (e.g., natural phenolic compounds, nisin, pentosin, chitosan, lysozyme); and (vii) hurdle technologies (i.e., a combination of existing and novel food preservation techniques). Variability in the effectiveness and applicability of the aforementioned methods, the need for further optimization/validation in some of them, intellectual property rights (IPRs), alterations in organoleptic traits of the product, health concerns (real or perceived) such as the possible carcinogenic effects of nitrates [10], and consumers' skepticism are driving the decision-making process of the meat industry toward their exploitation on an evidentiary case-by-case basis $[3,7,11,12]$.

To meet the ever-growing skepticism of the consumer, biocontrol and natural additive compounds for the prevention of meat oxidation, spoilage, and foodborne pathogens have emerged as novel preservation technologies. They exploit the antioxidant and antimicrobial properties of bacteriophage viruses and biomolecules (e.g., bacteriocins, natural organic acids, peptides and other groups of organic compounds) produced by lactic acid bacteria, plants, and animals. These compounds are used as biopreservatives according to the type (raw or cooked meat), specific conditions, (storing temperature, $\mathrm{pH}$, etc.), and targeted pathogens in meat and meat byproducts $[3,7,13]$. Among these compounds, naturally occurring phenols are considered promising substances against meat spoilage and foodborne pathogens. They are plant-derived biomolecules with proven industrial and consumer acceptance for their antioxidant and antimicrobial capabilities $[14,15]$.

The objectives of the present review are (i) to summarize the current knowledge about the applications of naturally occurring phenols in fresh meat, meat products, minced meat, and meat preparations, as defined in Regulation (EC) No 853/2004 [16], emphasizing on the mechanisms, determinants and spectrum of their antioxidant and antimicrobial activity, and (ii) to present state-of-the-art technologies utilized for the application of phenolic compounds in meat systems, and (iii) to discuss relevant regulation, limitations, perspectives, and future challenges for their mass industrial use.

\section{Meat Oxidation, Spoilage, and Foodborne Pathogens}

Oxidation of lipids and proteins in meat affect both its quality and safety. In addition to the organoleptic (flavor, aroma and color) and nutritional deterioration (denaturation of fatty acids and proteins), oxidation reduces the shelf-life of meat and derived products and undermines their safety due to production of toxic substances $[15,17]$. Oxidation is favored by the presence of polyunsaturated fatty acids in meat $[17,18]$. Double bonds in polyunsaturated fatty acids function as ideal initiators for the oxidation process reacting with atmospheric oxygen and other fatty acids and leading to the formation of hydroperoxides and free radicals [15]. The process continues until the final products, 
such as aldehydes, ketones, and hexanes, cannot further support the oxidation cycle [18]. In turn, the products of lipid oxidation and free radicals promote protein oxidation results in protein carbonylation, polymerization, and coagulation [19]. These chemical changes decrease protein solubility and prevent natural proteolysis, which adversely affects meat organoleptic traits, such as tenderness and juiciness $[17,20]$. Apart from the lipid and protein profile and content, the oxidation process is further influenced by other factors such as heat, light, metal ions, heme pigments, low $\mathrm{pH}$, and oxidative enzymes $[17,21]$.

Several foodborne illnesses linked to the consumption of contaminated, insufficiently cooked, or inadequately preserved meat and meat-based products are reported globally, undermining public health and causing significant monetary losses for the meat industry $[3,7,22]$. Incidence of foodborne illnesses associated with the consumption of meat and products thereof, apart from those attributed to major foodborne outbreaks, is likely to be underestimated, as corresponding cases remain underdiagnosed or unreported, particularly in countries with inefficient or inexistent monitoring programs [6,23,24]. Additionally, lipid and protein oxidation have been linked to cytotoxicity, neurotoxicity, mutagenicity and carcinogenesis $[19,25]$. In particular, the end-products of protein oxidation may constitute risk factors for cancer and diabetes [19], while the aldehyde groups originating from lipid oxidation have been linked to metabolic disorders and other diseases of the kidneys, the vasculature and the colon [26].

During the last decade, the annual cases of foodborne illnesses in humans in the EU have fluctuated without intense variation over the years [27]. In general, meat and meat products along with eggs and egg products are the top two most frequently reported food vehicles of animal origin pathogens associated with foodborne outbreaks in the EU [27]. Similarly, each year in the United States of America, meat and products thereof are responsible approximately for 30\% of total foodborne outbreaks and $50 \%$ of foodborne illness cases, and they represent the most commonly reported food vehicle of animal origin for the pathogens implicated in the corresponding human cases [28,29]. The main agents causing meat borne outbreaks in the EU and in the USA are Salmonella spp.; bacterial toxins produced by Bacillus spp., Staphylococcus spp., Clostridium spp. (other than Clostridium botulinum), and other unspecified bacterial toxins; Campylobacter spp., Trichinella spp., norovirus, and other caliciviruses; Cl. Botulinum; and other bacterial agents (such as Aeromonas hydrophila, enterotoxigenic Escherichia coli (ETEC), Enterococcus, Shigella spp., Yersinia enterocolitica, Shiga toxin-producing E. coli (STEC), and Listeria spp.) $[27,29]$.

\section{Natural Phenolic Compounds}

Natural phenolic compounds are biomolecules with at least one aromatic ring linked to hydroxyl substituents, and they are derived as secondary metabolites of plant tissues [14,30-32]. They contribute to the appearance, taste and basic functions of tissues and provide innate defensive functions in many plant species. Their classification is complex and can be based on their carbon chain length, the side groups of the aromatic ring, their distribution in nature, and the part of the plant they derive from [33]. Based on the molecular structure of their aromatic ring, they are classified into simple phenols and benzoquinones $\left(\mathrm{C}_{6}\right)$, phenolic acids $\left(\mathrm{C}_{6}-\mathrm{C}_{1}\right)$, acetophenones and phenylacetic acids $\left(C_{6}-C_{2}\right)$, hydroxycinnamic acids, phenylpropenes, coumarins-isocoumarins and chromones $\left(C_{6}-C_{3}\right)$, naphthoquinones $\left(C_{6}-C_{4}\right)$, xanthones $\left(C_{6}-C_{1}-C_{6}\right)$, stilbenes and anthraquinones $\left(C_{6}-C_{2}-C_{6}\right)$, flavonoids $\left(C_{6}-C_{3}-C_{6}\right)$, lignans and neolignans $\left(C_{6}-C_{3}\right)_{2}$, and lignins $\left(C_{6}-C_{3}\right)_{n}$ [33]. Natural phenolic compounds are abundant in plants and can be found in herbs, spices, vegetables, fruits, wine, essential oils, olive oil, and oil seeds [17,18]. Although they are non-nutritional components, they are utilized by the food industry for their antioxidant, antimicrobial, antifungal and antiviral functions [34].

Natural phenolic compounds with useful applications in food industry are (i) phenolic acids with one aromatic ring, further subdivided into the hydroxybenzoic acids (e.g., gallic, protocatechuic, vanillic, and syringic acid) and the hydroxycinnamic acids (e.g., p-coumaric, caffeic, and ferulic acid); the antioxidant activity of these compounds is related to the number of hydroxyl groups in their molecule; (ii) flavonoids (e.g., flavanols, flavones, flavanones, flavan-3-ols, isoflavones, 
anthocyanins), which constitute the largest subcategory in natural phenolics and their structure consists of a 15-carbon skeleton arranged in two phenyl rings and a heterocyclic ring; (iii) quinones made of two carbonyls (e.g., benzoquinones, anthraquinones); (iv) tannins, which are abundant in fruits and are formed by quinones or flavonoids; (v) coumarins with a combination of benzene and alpha-pyrone ring, which are potentially toxic but also useful for their antimicrobial activity if used properly; (vi) lignans; (vii) stilbenes; and (viii) curcuminoids [32,34-36]. Essential or volatile oils from plants have characteristic aromas and are composed of a mixture of several phenolic compounds which serve as the basic active ingredients (terpenes, terpenoids, and phenylpropanoids). Typical examples of essential oils rich in phenolic compounds that have been used in the food industry are prepared from oregano (carvacrol, thymol, p-cymene, $\gamma$-terpinene), clove (eugenol), coriander (linalool), ginger ( $\alpha$-pinene, cineole, borneol, geraniol, $\alpha$-curcumene, camphene and eucalyptol), rosemary (carnosic acid, carnosol, rosmadial, genkwanin, rosmarinic acid, 1,8-cineole, $\alpha$-pinene, limonene and camphor), sage ( $\alpha$-thujone, $\beta$-thujone, camphor, 1,8-cineole, borneol, viridiflorol), thyme (thymol, carvacrol, $\rho$-cymene, $\gamma$-terpinene, linalool), and mint (menthol) [34,37-39].

\subsection{Antioxidant Capacity of Phenolic Compounds}

Antioxidant substances prevent or hamper the oxidation chain reaction by capturing free radicals, reducing oxygen, deactivating singlet oxygen $\left({ }^{1} \mathrm{O}\right)_{2}$, conjugating the metal ions, eliminating the hydroperoxides, and absorbing UV light $[15,17,18]$. Phenolic compounds are considered effective antioxidants due to their ability to deactivate and stabilize free radicals by incorporating them into their aromatic ring $[17,18,21,40]$ and to absorb UV light [18]. The phenolic subgroup of flavonoids can also act as metal chelator, mainly for $\mathrm{Fe}^{3+}$, inhibiting the oxidation process $[18,21]$. Contrary to synthetic phenolic antioxidant substances, which have been used for decades in the food industry and are accused for toxicity and carcinogenesis [41-43], natural phenolic compounds have beneficial effects on human health by protecting against oxidative-stress-related chronic diseases [40,44-46]. Several studies have investigated the antioxidant capacity of phenolic compounds in meat and its organoleptic traits. Table 1 presents applications of antioxidant phenolic compounds in meat-based products, the effects of phenolic compounds on lipid and protein oxidation, and on product organoleptic traits (color, flavor, and taste). In addition, it summarizes the comparisons between phenolic compounds and conventional food additives regarding their antioxidant. Phenolic compounds are referred to only in cases where analytical laboratory techniques have been used to detect them. 
Table 1. Antioxidant effect of phenolic compounds in meat and meat-based products.

\begin{tabular}{|c|c|c|c|c|c|c|c|}
\hline Meat/Meat-Based Product & Treatment (Main Phenolic Compound) & LA $^{1}$ & $\mathbf{P A}^{2}$ & $\mathrm{COL}^{3}$ & FL/TA ${ }^{4}$ & FA $^{5}$ & $\operatorname{Ref}^{6}$ \\
\hline & \multicolumn{7}{|c|}{ Pork meat and meat-based products } \\
\hline Fresh meat & Lotus extract (tannins, flavonoids) & ++ & N/A & ++ & $0 /++$ & N/A & [47] \\
\hline \multirow{2}{*}{ Foal steaks } & Oregano essential oil (N/A)* & ++ & ++ & + & ++ & $\mathrm{N} / \mathrm{A}$ & [48] \\
\hline & Green tea extract $(\mathrm{N} / \mathrm{A}) *$ & ++ & ++ & 0 & 0 & & {$[48]$} \\
\hline \multirow{13}{*}{ Patties } & Rosemary extract (N/A) & ++ & + & 0 & N/A & AA (-) & \multirow{2}{*}{ [49] } \\
\hline & Green tea extract (N/A) & ++ & + & 0 & $\mathrm{~N} / \mathrm{A}$ & AA (-) & \\
\hline & Green tea extract (N/A) & ++ & N/A & ++ & N/A & & \multirow{2}{*}{ [50] } \\
\hline & Grape extract (N/A) & ++ & N/A & - & N/A & BHT (-) & \\
\hline & $\begin{array}{c}\text { Cudrania tricuspidata leaf powder } \\
\text { (flavonoids) }\end{array}$ & ++ & N/A & ++ & N/A & N/A & [51] \\
\hline & $\begin{array}{l}\text { Black currant (Ribes nigrum L.) extract } \\
\text { (anthocyanins) }\end{array}$ & ++ & ++ & + & 0 & $\mathrm{~N} / \mathrm{A}$ & [52] \\
\hline & $\begin{array}{c}\text { Licorice (Glycyrrhiza glabra) extract } \\
\text { [hispaglabridin (A and B), } \\
\text { glabridin, } 4^{\prime} \text {-O-methylglabridin, } \\
\text { isoprenylchalcone, liquiritigenin, } \\
\text { isoliquir-itigenin, formononetin] }\end{array}$ & ++ & N/A & N/A & + & BHA (0) & [53] \\
\hline & Tea polyphenols (catechins) * & ++ & N/A & ++ & ++ & N/A & [54] \\
\hline & Rosemary extract (N/A) & ++ & ++ & + & 0 & BHT (-) & \multirow{2}{*}{ [55] } \\
\hline & Lemon balm extract (N/A) & ++ & ++ & + & 0 & BHT (-) & \\
\hline & Grape seed extract (N/A) & ++ & N/A & 0 & 0 & $\mathrm{~N} / \mathrm{A}$ & \multirow{2}{*}{ [56] } \\
\hline & Bearberry extract (N/A) & ++ & N/A & 0 & 0 & N/A & \\
\hline & Berries extract (N/A) & ++ & N/A & N/A & N/A & N/A & [57] \\
\hline Meatballs & $\begin{array}{l}\text { Ginkgo biloba leaves extract (polyphenols, } \\
\text { phenolic acids, flavonols) }\end{array}$ & ++ & N/A & N/A & N/A & BHT (-) & [58] \\
\hline \multirow{5}{*}{ Liver pâté } & Chestnut extract (N/A) & ++ & N/A & $\mathrm{N} / \mathrm{A}$ & 0 & $\mathrm{BHT}(+)$ & \multirow{3}{*}{ [59] } \\
\hline & Grape extract (N/A) & ++ & $\mathrm{N} / \mathrm{A}$ & N/A & 0 & BHT (-) & \\
\hline & Tea extract (N/A) & ++ & N/A & N/A & 0 & BHT (-) & \\
\hline & Date palm by-products (N/A) & ++ & 0 & - & 0 & $\mathrm{~N} / \mathrm{A}$ & [60] \\
\hline & Date palm paste \& annatto extract (N/A) & + & N/A & N/A & N/A & N/A & [61] \\
\hline
\end{tabular}


Table 1. Cont.

\begin{tabular}{|c|c|c|c|c|c|c|c|}
\hline Meat/Meat-Based Product & Treatment (Main Phenolic Compound) & LA $^{1}$ & $\mathbf{P A}^{2}$ & $\mathrm{COL}^{3}$ & FL/TA ${ }^{4}$ & FA $^{5}$ & $\operatorname{Ref}^{6}$ \\
\hline \multirow{14}{*}{ Sausages } & Lutein (lutein) & $0 /+$ & N/A & 0 & 0 & N/A & \multirow{4}{*}{ [62] } \\
\hline & Seasamol (seasamol) & ++ & $\mathrm{N} / \mathrm{A}$ & 0 & 0 & $\mathrm{~N} / \mathrm{A}$ & \\
\hline & Ellagic acid (ellargic acid) & ++ & N/A & 0 & - & N/A & \\
\hline & $\begin{array}{c}\text { Olive leaf extract (Oleuropein, } \\
\text { verbascoside, luteolin- } \\
\text { 7-O-glucoside, apigenin-7-O-glucoside, } \\
\text { tyrosol, hydroxytyrosol) }\end{array}$ & ++ & N/A & 0 & 0 & N/A & \\
\hline & Grape seed extract (N/A) & ++ & $\mathrm{N} / \mathrm{A}$ & + & ++ & BHT (-) & \multirow{2}{*}{ [63] } \\
\hline & Chestnut extract (N/A) & ++ & $\mathrm{N} / \mathrm{A}$ & + & ++ & BHT (-) & \\
\hline & Adzuki bean extract (N/A) & ++ & N/A & $-/ 0$ & 0 & BHT (0) & {$[64]$} \\
\hline & Jaboticaba peel extract (N/A) & ++ & $\mathrm{N} / \mathrm{A}$ & 0 & 0 & N/A & {$[65]$} \\
\hline & Green tea extract (N/A) & ++ & - & - & 0 & N/A & \multirow{2}{*}{ [66] } \\
\hline & Rosemary extra (N/A) & ++ & - & - & - & $\mathrm{N} / \mathrm{A}$ & \\
\hline & Sage (N/A) & ++ & + & ++ & 0 & $\mathrm{~N} / \mathrm{A}$ & [67] \\
\hline & Lotus seed epicarp extract (flavonoids) & ++ & $\mathrm{N} / \mathrm{A}$ & N/A & $\mathrm{N} / \mathrm{A}$ & $\mathrm{N} / \mathrm{A}$ & {$[68]$} \\
\hline & Shiitake powder (N/A) & ++ & $\mathrm{N} / \mathrm{A}$ & 0 & + & $\mathrm{SN}(-)$ & [69] \\
\hline & Banana male flowers extract (flavonoids) & ++ & $\mathrm{N} / \mathrm{A}$ & 0 & 0 & N/A & [70] \\
\hline Bacon & Tea polyphenols (N/A) & ++ & N/A & N/A & N/A & TC (-) & [71] \\
\hline \multirow{3}{*}{ Ham } & $\begin{array}{l}\text { Garlic, cinnamon, clove and rosemary } \\
\text { essential oils (N/A) }\end{array}$ & ++ & ++ & ++ & N/A & $\begin{array}{l}\text { SC-SE } \\
{[\operatorname{LA}(-)} \\
\text { PA }(0)]\end{array}$ & \multirow[t]{2}{*}[72]{} \\
\hline & Rosa canina L. extract (N/A) & ++ & ++ & 0 & N/A & $\begin{array}{l}\text { SC-SE } \\
{[\mathrm{LA}(0)} \\
\operatorname{PA}(-)]\end{array}$ & \\
\hline & \multicolumn{7}{|c|}{ Beef meat and meat-based products } \\
\hline & Rosemary extract (carnosic acid, carnosol) & ++ & N/A & N/A & N/A & $\begin{array}{l}\text { BHT (-), } \\
\text { PG (+) }\end{array}$ & \multirow[t]{2}{*}{ [73] } \\
\hline Fresh meat & $\begin{array}{l}\text { Polyvinylpolypyrrolidone brewery } \\
\text { washing solution (benzoic acid derivatives, } \\
\text { flavan-3-ols, cinnamic acids, flavanones, } \\
\text { flavones, flavonols, acetophenone } \\
\text { derivates, stilbenoids) * }\end{array}$ & ++ & N/A & N/A & N/A & $\begin{array}{c}\text { BHT } \\
(-), P G(0)\end{array}$ & \\
\hline
\end{tabular}


Table 1. Cont.

\begin{tabular}{|c|c|c|c|c|c|c|c|}
\hline Meat/Meat-Based Product & Treatment (Main Phenolic Compound) & LA $^{1}$ & $\mathbf{P A}^{2}$ & $\mathrm{COL}^{3}$ & FL/TA ${ }^{4}$ & FA $^{5}$ & $\operatorname{Ref}^{6}$ \\
\hline & $\begin{array}{l}\text { Lotus rhizome knot and lotus leaf extracts } \\
\text { (tannins and flavonoids) }\end{array}$ & ++ & N/A & ++ & $0 /++$ & N/A & [47] \\
\hline & $\begin{array}{l}\text { Olive hydroxytyrosol or } \\
\text { 4-dihydroxyphenylglycol (hydroxytyrosol, } \\
\text { 4-dihydroxyphenylglycol) * }\end{array}$ & ++ & N/A & N/A & N/A & N/A & [74] \\
\hline \multirow{4}{*}{ Patties } & $\begin{array}{l}\text { Chamnamul (Pimpinella } \\
\text { brachycarpa) extract (N/A) }\end{array}$ & ++ & N/A & ++ & N/A & $\mathrm{BHT}(+)$ & \multirow[t]{2}{*}{ [75] } \\
\hline & Fatsia (Aralia elata) extract (N/A) & ++ & N/A & ++ & $\mathrm{N} / \mathrm{A}$ & $\mathrm{BHT}(0)$ & \\
\hline & Chestnut extract (N/A) & ++ & N/A & + & 0 & BHT & [76] \\
\hline & $\begin{array}{l}\text { Seasonings derived from wine pomace } \\
\qquad(\mathrm{N} / \mathrm{A})\end{array}$ & ++ & N/A & N/A & N/A & $\begin{array}{l}\text { Sulfites } \\
\qquad(-)\end{array}$ & [77] \\
\hline \multirow{3}{*}{ Meatballs } & Film with sage (Salvia officinalis) (N/A)* & ++ & N/A & 0 & - & N/A & \multirow{3}{*}{$\begin{array}{l}{[78]} \\
{[79]}\end{array}$} \\
\hline & Film with Laurus nobilis (N/A)* & ++ & N/A & 0 & - & $\mathrm{N} / \mathrm{A}$ & \\
\hline & Pomegranate peel extract (N/A) & ++ & ++ & + & 0 & BHT (-) & \\
\hline \multirow{5}{*}{ Sausages } & Grape seed extract (N/A) & ++ & N/A & + & + & $\begin{array}{c}\text { AA, PG } \\
(-)\end{array}$ & [80] \\
\hline & Green tea extract (N/A) & ++ & $\mathrm{N} / \mathrm{A}$ & + & 0 & N/A & \multirow{3}{*}{ [81] } \\
\hline & Stinging nettle extract (N/A) & ++ & $\mathrm{N} / \mathrm{A}$ & - & 0 & $\mathrm{~N} / \mathrm{A}$ & \\
\hline & Olive leaves extract (N/A) & ++ & N/A & - & 0 & N/A & \\
\hline & \multicolumn{7}{|c|}{ Poultry meat and meat-based products } \\
\hline \multirow{2}{*}{ Fresh meat } & $\begin{array}{l}\text { Pequi (Caryocar brasiliense) waste extract } \\
\text { (phenolic acids, flavonoids, anthocyanins) }\end{array}$ & ++ & ++ & - & N/A & BHT (-) & \multirow[t]{2}{*}{ [82] } \\
\hline & $\begin{array}{l}\text { Jucara (Euterpe edulis) waste extract } \\
\text { (phenolic acids, flavonoids, anthocyanins) }\end{array}$ & 0 & ++ & - & N/A & $\mathrm{BHT}(+)$ & \\
\hline \multirow{4}{*}{ Meat wafer } & Apple peel (N/A) & ++ & N/A & ++ & ++ & $\mathrm{N} / \mathrm{A}$ & \multirow{4}{*}{ [83] } \\
\hline & Banana peel (N/A) & ++ & N/A & ++ & ++ & $\mathrm{N} / \mathrm{A}$ & \\
\hline & Aloe vera gel (N/A) & ++ & N/A & ++ & ++ & $\mathrm{N} / \mathrm{A}$ & \\
\hline & Drumstick leaf powder (N/A) & ++ & N/A & ++ & ++ & N/A & \\
\hline Patties & $\begin{array}{c}\text { Pomegranate juice, pomegranate rind } \\
\text { powder extract (N/A) }\end{array}$ & ++ & N/A & 0 & 0 & BHT (-) & [84] \\
\hline
\end{tabular}


Table 1. Cont.

\begin{tabular}{|c|c|c|c|c|c|c|c|}
\hline Meat/Meat-Based Product & Treatment (Main Phenolic Compound) & LA $^{1}$ & $\mathbf{P A}^{2}$ & $\mathrm{COL}^{3}$ & FL/TA 4 & FA $^{5}$ & Ref $^{6}$ \\
\hline & \multicolumn{7}{|c|}{ Lamb meat and meat-based products } \\
\hline \multirow{4}{*}{ Patties } & Tomato by-products extract (N/A) & 0 & 0 & 0 & N/A & SA $(0)$ & \multirow{4}{*}{ [85] } \\
\hline & Red grape by-products extract (N/A) & ++ & ++ & 0 & N/A & SA (-) & \\
\hline & Olive by-products extract (N/A) & ++ & ++ & 0 & $\mathrm{~N} / \mathrm{A}$ & SA (-) & \\
\hline & Pomegranate by-products extract (N/A) & 0 & 0 & 0 & N/A & SA (0) & \\
\hline Burger & $\begin{array}{l}\text { Origanum vulgare extract (rosmarinic acid, } \\
\text { cathechin/ epicatechin derivative, } \\
\text { 4-(3,4-Dihydroxybenzoyloxymethyl)phenyl- } \\
\beta \text {-D-glucopyranoside, naringenin) }\end{array}$ & ++ & ++ & + & 0 & SE (-) & [86] \\
\hline \multirow[t]{2}{*}{ Sausages } & Origanum vulgare extract (N/A) & ++ & ++ & - & $0 /-$ & SE (0) & [87] \\
\hline & \multicolumn{7}{|c|}{ Mixed meat sausages } \\
\hline Sucuk & Green tea extract (N/A) & ++ & N/A & 0 & ++ & BHT (-) & [eе] \\
\hline (lamb- beef) & Thymbra spicata oil (N/A) & ++ & N/A & 0 & ++ & BHT (-) & {$[88]$} \\
\hline Poultry- pork & Nutmeg essential oil (N/A) & ++ & N/A & 0 & ++ & N/A & [89] \\
\hline
\end{tabular}

${ }_{1}^{1}$ lipid antioxidant effect, ${ }^{2}$ protein antioxidant effect, ${ }^{3}$ color effect, ${ }^{4}$ flavor/taste effect, ${ }^{5}$ food additives other than phenolic compound (in this column, the brackets indicate equal (0), increased $(+)$ or decreased $(-)$ antioxidant capacity of food additives compared to phenolic compounds), ${ }^{6}$ references. ${ }^{*}$ application of phenolic treatment in packaging. $+:$ poor positive effect, ++: strong positive effect, -: negative effect, 0 : no effect (columns LA, PA, COL, and FL/TA; the grading system reflects the opinion/conclusions of the corresponding referenced citation). AA: ascorbic acid, BHT: butylated hydroxytoluene, BHA: butylated hydroxyanisole, SN: sodium nitrite, TC: $\alpha$-tocopherol, SC-SE: sodium citrate- sodium erythorbate, PG: propyl gallate, SA: sodium ascorbate, N/A: relative data is not available. 


\subsection{Antimicrobial Activity of Phenolic Compounds}

\subsubsection{Antimicrobial Activity Mechanisms}

Many phenolic compounds serve as efficient antimicrobial agents $[34,37,90]$. The mechanisms of their antimicrobial properties have not been completely clarified as yet; however, the prevalent hypothesis is that they do so by destabilizing the microbial cell surface and cytoplasmic membranes [37,91-94]. This may lead to irreversible damage of the cell wall and various intracellular organelles, coagulation of cell compartments, and inhibition of intracellular enzymes. In particular, the hydrophobic phenolic compounds are bound by the lipid bilayer of the microbial cell membrane causing its structural disruption and loss of integrity $[95,96]$, leading to the creation of pores, the flow of intracellular components in the extracellular space, and the functional dysregulation of proteins such as the $\mathrm{Na}^{+} / \mathrm{K}^{+}$-ATPase pump [96-98]. In addition, the phenolic ring, due to its hydroxyl group and the indispensable double bonds, has the capacity to act as a transmembrane transporter of cations, causing influx of $\mathrm{H}^{+}$, efflux of $\mathrm{K}^{+}$, and suppression of ATP synthesis $[99,100]$. Phenolic compounds may interact with intracellular components and DNA after disruption of the cell wall and entry into the cell $[95,100]$. The destruction of intracellular membranes causes release of free radicals that in turn can lead to DNA damage and lipid oxidation. As an adaptive response to this phenolic "attack," microbes modify their gene expression to reduce aerobic metabolism and increase production of antioxidant and DNA repair enzymes [101,102]. Suppression of aerobic metabolism by itself restricts microbe motility and biofilm formation, which are conditions that favor survival.

\subsubsection{Antimicrobial Activity Associated Factors}

The antimicrobial activity of natural phenolic compounds mainly depends on their chemical structure and concentration. Several additional factors, however, have been identified that could limit the antimicrobial activity of the phenolic compounds when applied in meat systems. The antimicrobial activity is adversely affected by increased $\mathrm{pH}$; low water activity; and salt, fat, and complex carbohydrate content [34,91,103-106]. Reduced $\mathrm{pH}$ and increased concentration of phenolic substances enhance the hydrophobicity of essential oils favoring their attachment to the pathogen's lipid cell membranes and therefore, their antimicrobial activity $[104,105,107]$. In general, the hydrophobic nature of phenolic compounds facilitates their accumulation in fat [108]. The high concentration of fat in meat does not favor the contact between phenolic compounds and the pathogenic microorganisms that accumulate in the hydrophilic phase of meat [91,106]. Proteins create strong complexes with phenolic compounds, and this may reduce their antioxidant and antimicrobial capacity. However, the results from relative studies are contradictory, and the effect of proteins on antimicrobial or antioxidant activity of phenolic compounds is not clarified [109]. Finally, high temperature can eliminate the antimicrobial activity of natural phenolic compounds particularly during packaging [34], while low storage temperature favors it $[106,108]$.

Synergistic and antagonistic interactions contribute to the antimicrobial activity of phenolic compounds; however, the mechanisms have not been yet elucidated. These interactions are observed when phenolic substances are used in combination or in cases of essential oils which contain more than one phenolic compound [39]. The fortified or reduced antimicrobial activity of essential oils compared to that of individual phenolic compounds reveals the synergistic or antagonistic interactions, respectively $[39,97,110]$. For example, carvacrol (the main phenolic compound of oregano oil) and a fraction of dill oil with d-limonene and carvone when compared with crude essential oils demonstrated increased antimicrobial capacity, indicating that there is an antagonistic interaction between some of their components [39,111]. Examples of synergistic action have been documented in the following combinations of phenolic compounds: (i) carvacrol, thymol, and eugenol against Listeria innocua; (ii) carvacrol and p-cymene against Bacillus cereus; (iii) cinnamaldehyde and eugenol against Staphylococcus spp., Micrococcus spp., Bacillus spp., and Enterobacter spp. [39,97]; (iv) carvacrol and thymol against E. coli O157:H7, Staphylococcus aureus, L. innocua, Saccharomyces cerevisiae, and 
Aspergillus niger [34]; (v) geraniol and menthol against S. aureus; (vi) thymol and menthol against B. cereus [112]; and (vii) cranberry (ellagic acid) and oregano (rosmarinic acid) extract against Listeria monocytogenes $[104,113]$. Synergistic interactions between phenolic compounds and antibiotics against foodborne pathogens have also been observed. For example, the combination of green tea extract with oxacillin is effective against S. aureus [114]; gallic acid with amikacin, norfloxacin, gentamicin, and sulfamethoxazole [115] or catechin and ciprofloxacin [116] against E. coli; p-coumaric acid, sinapic acid, caffeic acid, vanillic acid, gallic acid, and taxifolin with ciprofloxacin and erythromycin against Campylobacter jejuni [117]; and ellagic and tannic acids with ovobiocin, coumermycin, chlorobiocin, rifampicin, and fusidic acid against Acinetobacter baumannii [118]. The aforementioned synergistic interactions may indicate that one phenolic compound facilitates the antimicrobial function of another compound or antibiotic and vice versa; e.g., the phenolic compound initiates cell membrane rupture facilitating the entry of an antibiotic compound [97].

\subsubsection{Antimicrobial Activity Spectrum}

\section{In Vitro Antimicrobial Activity of Phenolic Compounds}

Several in vitro studies have demonstrated the antimicrobial properties of natural phenolic compounds against foodborne pathogens. Regardless of their chemical structure, phenolic compounds act primarily against Gram-positive and to a lesser extent on Gram-negative bacteria (Table 2). The list of Gram-positive bacteria inhibited by various essential oils and spices is remarkable (see Table 2).

Table 2. In vitro antimicrobial activity of phenolic compounds or fractions.

\begin{tabular}{|c|c|c|}
\hline Phenolic Compound & Targeted Microorganisms & $\operatorname{Ref}^{1}$ \\
\hline \multicolumn{3}{|c|}{ Phenolic acids } \\
\hline p-coumaric acid & $\begin{array}{c}\text { Saccharomyces cerevisiae, Escherichia coli, Salmonella enterica serovar Typhimurium, } \\
\text { MRSA, Staphylococcus aureus, Bacillus subtilis, Shigella dysenteriae, Streptococcus } \\
\text { pneumoniae }\end{array}$ & {$[90,100,119]$} \\
\hline Ferulic acid & S. cerevisiae, Lactobacillus plantarum, S. aureus, Staphylococcus epidermidis, MRSA & {$[90,119]$} \\
\hline Caffeic acid & $\begin{array}{c}\text { L. plantarum, E. coli, S. aureus, S. epidermidis, MRSA, Serratia marcescens, Proteus } \\
\text { mirabilis }\end{array}$ & {$[90,119,120]$} \\
\hline Gallic acid & E. coli, S. aureus. Klebsiella pneumoniae & {$[120,121]$} \\
\hline Vanillic cid & E. coli, S. aureus, MRSA, P. mirabilis, K. pneumonia, Candida albicans, C. neoformans & {$[119,120,122]$} \\
\hline Protocatechuic acid & E. coli, S. aureus, L. monocytogenes, Streptococcus agalactiae & {$[119,120]$} \\
\hline Syringic acid & MRSA, L. monocytogenes & [119] \\
\hline 2,4-dihydroxybenzoic acid & E. coli, MRSA, Enterococcus faecalis & [119] \\
\hline \multicolumn{3}{|c|}{ Flavonoids } \\
\hline Epicatechin & $\begin{array}{c}\text { E. coli, E. coli O157:H7, S. enterica serovar Choleraesuis, Salmonella enterica serovar } \\
\text { Enteritidis, Salmonella enterica serovar Paratyphi }\end{array}$ & [123] \\
\hline Epigallocatechin & E. coli, Salmonella spp., S. aureus, Vibrio spp. & [124] \\
\hline Epigallocatechin-3-O-gallate & E. coli, Salmonella spp., S. aureus, Vibrio spp. & [124] \\
\hline Procyanidins & S. aureus & [124] \\
\hline Theaflavins & S. aureus, Vibrio spp. & [124] \\
\hline Prodelphinidin & E. coli, Salmonella spp., S. aureus, Vibrio spp. & \\
\hline Myricetin & E. coli, E. coli O157:H7, S. Choleraesuis, S. Enteritidis, S. Paratyphi & [123] \\
\hline Quercetin & $\begin{array}{l}\text { E. coli, E. coli O157:H7, S. Choleraesuis, S. Enteritidis, S. Paratyphi, S. marcescens, } \\
\text { P. mirabilis, K. pneumonia }\end{array}$ & $\begin{array}{l}{[123]} \\
{[120]}\end{array}$ \\
\hline Rutin & $\begin{array}{l}\text { E. coli, E. coli } \mathrm{O} 157: \mathrm{H} 7, \text { S. Choleraesuis, S. Enteritidis, S. Paratyphi, S. marcescens, } \\
\text { P. mirabilis, K. pneumoniae, Pseudomonas aeruginosa, Acinetobacter baumannii }\end{array}$ & $\begin{array}{c}{[123]} \\
{[120,125]}\end{array}$ \\
\hline Xanthohumol & E. coli, E. coli O157:H7, S. Choleraesuis, S. Enteritidis, S. Paratyphi & [123] \\
\hline \multicolumn{3}{|c|}{ Quinones } \\
\hline Thymoquinone & E. coli, E. coli O157:H7, S. Choleraesuis, S. Enteritidis, S. Paratyphi & [123] \\
\hline Hydroquinone & S. aureus & [121] \\
\hline \multicolumn{3}{|c|}{ Tannins } \\
\hline Tannins & L. plantarum & [126] \\
\hline Castalagin & E. coli, Salmonella spp., S. aureus, Vibrio spp. & [124] \\
\hline Punicalagin & S. aureus, Vibrio spp. & [124] \\
\hline Tannic acid & S. aureus, Vibrio spp. & [124] \\
\hline Geraniin & S. aureus, Vibrio spp. & [124] \\
\hline
\end{tabular}


Table 2. Cont.

\begin{tabular}{|c|c|c|}
\hline Phenolic Compound & Targeted Microorganisms & $\operatorname{Ref}^{1}$ \\
\hline \multicolumn{3}{|c|}{ Coumarins } \\
\hline Coumarin & E.coli, S. Typhimurium, Salmonella enterica serovar Infantis, Enterobacter aerogenes & [127] \\
\hline \multicolumn{3}{|c|}{ Curcuminoids } \\
\hline Curcumin & E. coli, E. coli O157:H7, S. Choleraesuis, S. Enteritidis, S. Paratyphi & [123] \\
\hline \multicolumn{3}{|c|}{ Other polyphenols } \\
\hline Chlorogenic acid & E. coli, E. coli O157:H7, S. Choleraesuis, S. Enteritidis, S. Paratyphi & [123] \\
\hline \multicolumn{3}{|c|}{ Terpenes } \\
\hline Carvacrol & E. coli, STEC, S. aureus, $P$. fluorescens, Bacillus cereus & {$[112,121]$} \\
\hline Carvone & S. aureus & [112] \\
\hline Eugenol & $\begin{array}{l}\text { E. coli, E. coli O157:H7, S. Choleraesuis, } S \text {. Enteritidis, S. Paratyphi, S. aureus, } \\
\text { B. cereus }\end{array}$ & {$[112,123]$} \\
\hline Thymol & $\begin{array}{l}\text { E. coli, E. coli O157:H7, STEC, S. Choleraesuis, S. Enteritidis, S. Paratyphi, S. } \\
\text { aureus, Pseudomonas fluorescens, B. cereus }\end{array}$ & {$[121,123]$} \\
\hline \multicolumn{3}{|c|}{ Phenolic fractions } \\
\hline Scrophularia frutescens & Bacillus sp. & [128] \\
\hline Ginkgo biloba & $\begin{array}{l}\text { E. coli, S. Typhimurium, S. aureus, Listeria monocytogenes, Listeria innocua, } \\
\text { Streptococcus pyogenes, Shigella dysenteriae, E. aerogenes, Vibrio vulnificus }\end{array}$ & [129] \\
\hline Oil vegetation water & $\begin{array}{c}\text { LAB, E. coli O:157 H7, S. Typhimurium, S. aureus, S. xylosus, L. monocytogenes, L. } \\
\text { innocua, Pseudomonas spp. }\end{array}$ & [130] \\
\hline Olive oil & Campylobacter jejuni, C. coli & [131] \\
\hline Garlic & E. coli, S. aureus & [132] \\
\hline
\end{tabular}

Gram-negative bacteria are less sensitive to the antimicrobial activity of phenolic compounds $[91,106,121,133]$ due to the hydrophilic outer membrane of lipopolysaccharides that hinders entry of lipophilic phenolic molecules [95]. Nevertheless, phenolic compounds from berries (anthocyanins, flavonols and hydroxy-cinnamates) have proved to be somewhat active against Salmonella spp. (Gram negative) but not against Gram positive bacteria [134]. Also, a citrus oil called Brazilian orange terpenes, has presented higher antibacterial action against $E$. coli (Gram negative) than Lactobacillus rhamnosus (Gram positive) [135].

In Situ Antimicrobial Activity of Phenolic Compounds in Meat Systems

Various studies have been conducted in situ for the verification of antimicrobial activity of phenolic compounds in meat-based products. In these studies, phenolic compounds were used mainly in the form of essential oils and plant extracts and their efficiency against a wide range of pathogens was assessed under various combinations of substances, concentrations, and types of meat. Successful applications of several natural antimicrobials containing phenolic compounds are shown in Table 3. 
Table 3. In situ antimicrobial activity of natural phenolic compounds in meat-based products.

\begin{tabular}{|c|c|c|c|c|}
\hline Meat/Meat-Based Products & Treatment & Targeted Microorganisms & FA $^{1}$ & $\operatorname{Ref}^{2}$ \\
\hline \multicolumn{5}{|c|}{ Pork meat and meat-based products } \\
\hline Foal steak & Oregano $(\mathrm{O}) *$ & $\begin{array}{c}\text { TVC, LAB } \\
\text { Pseudompnas snn Enter }\end{array}$ & N/A & [48] \\
\hline \multirow[t]{2}{*}{ Patties } & $\begin{array}{l}\text { Green tea }(\mathrm{E}) \\
\text { Grape }(\mathrm{E})\end{array}$ & $\begin{array}{l}\text { TVC, LAB, psychrotrophic anaerobic bacteria, Pseudomonas } \\
\text { spp. }\end{array}$ & BHT (-) & [50] \\
\hline & Tea polyphenols $(\mathrm{P})$ * & TVC & N/A & [54] \\
\hline \multirow{5}{*}{ Sausages } & Rosemary $(\mathrm{E})$ & Enterobacteriaceae, Pseudomonas spp., yeasts, molds & $\mathrm{CH}(0), \mathrm{TC}(-)$ & [136] \\
\hline & Olive mill wastewater $(\mathrm{E})$ & Molds & Ethanol (-) & [137] \\
\hline & Olive vegetation water $(\mathrm{E})$ & Staphylococcus spp., molds & N/A & [138] \\
\hline & Oregano $(\mathrm{O})$ & Aerobic heterotrofic bacteria, Escherichia coli & N/A & $\begin{array}{l}{[139,} \\
140]\end{array}$ \\
\hline & Shiitake $(\mathrm{P})$ & TVC & $\mathrm{SN}(0)$ & [69] \\
\hline \multirow{2}{*}{ Liver pâté } & Date palm and annatto (E) & TVC & N/A & [61] \\
\hline & Pomegranate peel (E) & Listeria monocytogenes & $\mathrm{N} / \mathrm{A}$ & [141] \\
\hline Ham & Carvacrol, cinnamaldehyde * & L. monocytogenes & N/A & [142] \\
\hline Hamburger & Cranberry pomace $(\mathrm{E})$ & $\begin{array}{c}\text { LAB, TVC, L. monocytogenes, Brochothrix thermosphacta, } \\
\text { Pseudomonas putida }\end{array}$ & N/A & [143] \\
\hline \multirow{3}{*}{ Bacon } & Tea polyphenols, grape seed (E) & TVC, Enterobacteriaceae, Micrococcaceae, yeasts, molds & TC (-) & [711] \\
\hline & Gingerol & TVC, Enterobacteriaceae, Micrococcaceae & & {$[/ 1]$} \\
\hline & Liquid smoke & $\begin{array}{l}\text { E. coli, Salmonella enterica serovar Choleraesuis, } \\
\text { Staphylococcus aureus, L. monocytogenes }\end{array}$ & N/A & [144] \\
\hline \multirow[t]{2}{*}{ Salami } & Olive mill wastewater (E) & L. monocytogenes & Nitrate (-) & [14] \\
\hline & \multicolumn{4}{|c|}{ Beef meat and meat-based products } \\
\hline \multirow{4}{*}{ Fresh meat } & Oregano $(\mathrm{O})$ & S. aureus & $\mathrm{AC}(-)$ & [145] \\
\hline & Oregano and cranberry (EP) & L. monocytogenes & LA (-) & [104] \\
\hline & $\begin{array}{l}\text { Grape seed }(\mathrm{E}) \\
\text { Pine bark }(\mathrm{E})\end{array}$ & $\begin{array}{l}\text { E. coli O157:H7, Salmonella enterica serovar Typhimurium, } L . \\
\text { monocytogenes }\end{array}$ & BHA/BHT (-) & [103] \\
\hline & Malpighia punicifolia (E) & B. thermosphacta, Pseudomonas spp. & $\mathrm{N} / \mathrm{A}$ & [146] \\
\hline
\end{tabular}


Table 3. Cont

\begin{tabular}{|c|c|c|c|c|}
\hline Meat/Meat-Based Products & Treatment & Targeted Microorganisms & FA $^{1}$ & Ref $^{2}$ \\
\hline \multirow{4}{*}{ Minced meat } & Sage $(\mathrm{O})$ & $\begin{array}{c}\text { TVC, Enterobacteriaceae, Salmonella enterica serovar } \\
\text { Anatum, Salmonella enterica serovar Enteritidis, S. aureus, } \\
\text { Bacillus cereus, yeasts, molds }\end{array}$ & N/A & [147] \\
\hline & Prickly pear $(\mathrm{E})$ & TVC, Enterobacteriaceae, Pseudomonas spp. & N/A & [148] \\
\hline & $\begin{array}{c}\text { Pistacia lentiscus }(\mathrm{O}) \text { Satureja } \\
\text { montana }(\mathrm{O})\end{array}$ & L. monocytogenes & N/A & [149] \\
\hline & Rumex tingitanus (E) & L. monocytogenes & N/A & [150] \\
\hline \multirow{4}{*}{ Patties } & Thymol & Enterobacteriaceae, Coliforms & N/A & [151] \\
\hline & Wine pomace seasoning & TVC, LAB & Sulfites $(+)$ & [152] \\
\hline & Grape pomace $(\mathrm{E})$ & Coliforms, Enterobacteriaceae, yeasts, molds & $\mathrm{N} / \mathrm{A}$ & [153] \\
\hline & Chamnamul and fatsia (E) & Coliforms & BHT (0) & {$[75]$} \\
\hline \multirow[t]{2}{*}{ Sucuk } & Black carrot concentrate & Yeasts, molds & SN (-) & [154] \\
\hline & & Poultry meat and meat-based products & & \\
\hline \multirow{6}{*}{ Fresh meat } & Carvacrol, cinnamaldehyde & E. coli O157:H7, S. Enteritidis & $\mathrm{N} / \mathrm{A}$ & [142] \\
\hline & Carvacrol vapor & S. Enteritidis, & N/A & [155] \\
\hline & Oregano $(\mathrm{O})$ & $\begin{array}{c}\text { LAB, Enterobacteriaceae, } B \text {. thermosphacta, Pseudomonas } \\
\text { spp., yeasts }\end{array}$ & N/A & [156] \\
\hline & Pomegranate $(\mathrm{E})$ & Salmonella enterica serovar Kentucky, S. Enteritidis & N/A & [157] \\
\hline & Zanthoxylum rhetsa $(\mathrm{E})$ * & TVC, Staphylococcus spp., Coliforms & N/A & [158] \\
\hline & Eugenol * & Campylobacter jejuni & $\mathrm{AC}(-)$ & [102] \\
\hline Minced meat & Clove $(\mathrm{O})$ * & S. Typhimurium, L. monocytogenes & N/A & [159] \\
\hline Sausages & $\begin{array}{l}\text { Rosemary, Chinese mahogany } \\
\text { (E) }\end{array}$ & TVC & N/A & [160] \\
\hline \multirow[t]{2}{*}{ Salami } & Prickly pear (E) & LAB, Staphylococcus spp. & $\mathrm{SN}-\mathrm{CO}(-)$ & [161] \\
\hline & & Lamb meat and meat-based products & & \\
\hline Fresh meat & $\begin{array}{l}\text { Oregano }(\mathrm{O}) \\
\text { Thyme }(\mathrm{O})\end{array}$ & $\begin{array}{l}\text { TVC, Enterobacteriaceae } \\
\text { Pseudomonas spp. }\end{array}$ & N/A & [162] \\
\hline
\end{tabular}


Table 3. Cont.

\begin{tabular}{|c|c|c|c|c|}
\hline Meat/Meat-Based Products & Treatment & Targeted Microorganisms & FA $^{1}$ & $\operatorname{Ref}^{2}$ \\
\hline \multirow{4}{*}{ Patties } & \multirow{4}{*}{$\begin{array}{l}\text { Tomato by-products }(\mathrm{E}) \\
\text { Pomegranate by-products }(\mathrm{E}) \\
\text { Red grape by-products }(\mathrm{E}) \\
\text { Olive by-products }(\mathrm{E})\end{array}$} & Mesophile and psycrotrophic microorganisms, & & \multirow{4}{*}{ [85] } \\
\hline & & Enterobacteriaceae & SA $(0)$ & \\
\hline & & \multirow[t]{2}{*}{ Mesophile microorganisms } & & \\
\hline & & & SA $(0)$ & \\
\hline \multirow[t]{2}{*}{ Minced meat } & Oregano $(\mathrm{O})$ & S. Enteritidis & Nisin (-) & [163] \\
\hline & \multicolumn{4}{|c|}{ Mixed meat sausages } \\
\hline \multirow{3}{*}{ Beef \& pork } & $\begin{array}{l}\beta \text {-resorcylic acid, carvacrol, } \\
\text { trans-cinnamaldehyde }\end{array}$ & L. monocytogenes & DMSO (-) & [164] \\
\hline & Cranberry $(\mathrm{P})$ & L. monocytogenes & NLD (0) & [165] \\
\hline & Kitaibelia vitifolia (E) & E. coli & N/A & [166] \\
\hline Poultry \& pork & Nutmeg essential (O) & TVC & N/A & [89] \\
\hline
\end{tabular}

1 food additive other than phenolic compound (in this column, the brackets indicate: equal (0), increased (+) or decreased (-) antimicrobial capacity of food additives compared to phenolic compounds) ${ }^{2}$ references, ${ }^{*}$ application of phenolic treatment in packaging; O: oil, E: extract, P: powder, TVC: total viable count, LAB: lactic acid bacteria, BHT: butylated hydroxytoluene, CH: chitosan, TC: $\alpha$-tocopherol, SN: sodium nitrite, AC: acetic acid, LA: lactic acid, BHA: butylated hydroxyanisole, CO: cochineal, SA: sodium ascorbate, DMSO: dimethylsulfoxide, NLD: nitrite, lactate and diacetate. 


\section{Application of Phenolic Compounds in Meat}

\subsection{Direct Application in Meat}

Additives containing phenolic compounds can be either incorporated directly into meat-based products or in bio-based functional packaging materials. Herbs and spices or their extracted oils can be added as such, thus exploiting their distinct flavor $[34,103,167]$. The most appropriate application of herbs and spices on meat products depends on the phenolic compounds of the extracted essential oils and their antimicrobial properties (e.g., targeted microorganisms) [34]. Effectiveness depends on the type of application and could even vary in the same or similar meat products [168].

Active food packaging using bio-based materials that also incorporate phenolic compounds is an emerging technology. The packaging material in these cases could protect meat against oxidation and spoilage $[3,17,34,169,170]$. Currently, active packaging includes sachet-based applications gradually releasing phenolic compounds, pads with incorporated phenolic compounds and in direct contact with the product, edible or polyethylene bioactive films coated with essential oils [34,73,169,171-173]. Techniques for the incorporation of phenolic compounds into packaging films is complex and needs to account for factors such as heat and pressure applied during processing and packaging. These factors can adversely affect the molecular structure and therefore the functionality of the incorporated phenolic compounds [174]. During the manufacturing of active packaging materials, microencapsulation of phenolic compounds is currently exploited to protect their molecular structure and secure their antioxidant and antimicrobial activity $[73,175]$. State-of-the-art nanotechnologies that have been exploited in food nano-encapsulation applications include (i) biopolymer and lipid-based nanoparticles and cyclodextrins; (ii) nano-emulsions; (iii) nano-spray drying; and (iv) electro-spinning [174-178]. These technologies facilitate the carriage and delivery of phenolic compounds, protecting them from challenging conditions within food (e.g., $\mathrm{pH}$, temperature, and other organic compounds). Additionally, they improve their solubility and bioavailability, and mitigate the risk of developing undesirable flavors $[175,179,180]$.

\subsection{Incorporation in Animal Diets}

The addition of phenolic compounds in animal diets has been used to improve the antioxidant capacity of the produced meat. In ruminants, natural phenolic compounds have been related with (i) inhibitory effect on fibrolytic bacteria and protozoa, (ii) reinforcement of rumen bypass of polyunsaturated fatty acids and protein metabolism, and (iii) the production of conjugated linoleic acid [181-183] contributing to the qualitative improvement of the derived meat products. In monogastric animals, phenolic compounds have been found to act beneficially for the intestinal microbiota and the stability of polyunsaturated fatty acids in the intestine and muscle tissues [184]. For example, in broilers, incorporation of polyphenols extracted from the industrial waste of olive oil processing in their diets improved the antioxidant capability of their meat [185]. Similarly, the addition of gallic and linoleic acid to broiler diets had beneficial effects on their lipid metabolism, their productivity, the nutritional value and quality of meat, and its antioxidant and antimicrobial capacity [186], whereas oregano and laurel oil improved growth rate and reduced lipid oxidation [187]. Feeding rosemary extract in turkeys had a beneficial effect against lipid oxidation and spoilage of their meat [188]. In goats, consumption of tannin-rich leaves from woody plants improved the oxidative stability of the derived meat due to modulation of the fatty acid profile [189]. In rabbits and lambs, consumption of chestnut tannins increased their immune response under stress conditions, and improved growth rate, meat quality and antioxidant capacity [190,191]. In pig diets, incorporation of wood extract and oregano oil increased the presence of antioxidant enzymes in animals, prevented lipid oxidation and improved meat color [192]. Similarly, the addition of rosemary extract in lamb diets delayed lipid oxidation, color deterioration, and bacterial spoilage of the produced carcass [193], whereas tannins and oregano oil improved antioxidant status and color of meat $[194,195]$. Hence, the improvement of meat antioxidant and antimicrobial capacity results both from the direct accumulation of the phenolic compounds in 
meat and their indirect activity, which reinforces the health and welfare status of animals, therefore mitigating the oxidative stress and the respective degradation of their products.

\section{Regulation, Limitations, and Challenges in the Use of Phenolic Compounds}

Health risk assessment of phenolic compounds (essential oils, extracts and purified compounds) is necessary prerequisite for their commercial use in food products. This means that the inclusion of phenolic compounds in food legislation and their subsequent approval for commercial use by the meat industry, demand scientific evidence and the conduction of relevant risk assessment considering human health. This implies that the safety, health, and quality claims of phenolic compounds when applied in meat systems should be documented; records available by the European Food Safety Authority and corresponding committees of other countries need to be considered as well. This process is cost-intensive and time-consuming particularly when purified phenolic compounds are to be used [97], limiting their industrial application.

To date, the European Commission has approved (EU, 1333/2008 and 1129/2011) the application of rosemary extract (E392) as a food additive for meat products to concentration up to $150 \mathrm{mg} / \mathrm{kg}$ [38,196,197] and several other phenolic compounds (linalool, thymol, eugenol, carvone, cinnamaldehyde, vanillin, carvacrol, citral, and limonene) in the list of food flavoring substances, as described in the Regulation (EU) No 872/2012 [198]. Rosemary extract has been also approved for use in food industry in Japan, China [196], the US, and recently in Australia and New Zealand (Australia New Zealand Food Standards Code-Standard 1.3.1-Food Additives). The use of phenolic compounds in active food packaging (e.g., edible films, encapsulation) according to the Regulation (EU) No 450/2009 demands their incorporation in the list of approved food additives, given that they come into contact with food [199]. Likewise, the Food and Drug Administration (FDA) in the US has included several essential oils containing phenolic compounds such as clove, oregano, thyme, nutmeg, basil, mustard, cinnamon oil, and even estragole (prohibited in EU as genotoxic) in the list of Generally Recognized as Safe (GRAS) substances [39,97]. Hence, the commercial use of phenolic compounds in meat-based products to exploit their antioxidant and anti-spoilage activity is currently scarce.

Phenolic compounds naturally occurring in fruits and vegetables or produced by microorganisms could modify food flavor [90]. Several extracts and essential oils from fruits and vegetables (e.g., citrus, carrots, potatoes, orange, oregano) give sweet, sour, bitter, or astringent flavor due to their phenolic content, which precludes their unconditional use in meat preparations and meat products $[7,15,91,106,156,165]$. Adoption of the recommended concentrations, addition of modulatory substances like salt [91] and application of appropriate technologies, like micro-encapsulation of phenolic compounds, are significant measures to mitigate undesirable effects of phenolic compounds on organoleptic traits of meat-based products $[15,180]$.

The interaction of phenolic compounds with meat components (lipids, proteins, carbohydrates) and their effect on intrinsic quality traits of meat (e.g., $\mathrm{pH}$, organoleptic attributes) limits their wide application [37,39]. Although phenolic compounds are considered to decrease the digestibility of carbohydrates and proteins, inhibit the bioavailability of amino acids and bind the available iron, these effects have not been observed in meat $[90,109]$. In any case, further in situ experiments are necessary to evaluate the activity and possible anti-nutritional effects of natural phenolic compounds in meat-based products under various conditions.

Phenolic compounds are commonly added in meat in the form of essential oils. However, the intrinsic composition of each essential oil and its interrelated antimicrobial capacity depend mainly on the plant species and also, on the season, the age and the origin of the plant, environmental factors that can affect its phenotypic expression and the used extraction process (e.g., solvent extraction, fermentation, distillation, effleurage) $[97,149,200-202]$. Also, the source of natural phenolic compounds determines their purity and, therefore, their antimicrobial capability [123]. Finally, the cost for the extraction of natural phenolic compounds is affected by the degree of purification and the improvement of extract quality by removing potentially toxic organic components [203]. Protocols to standardize the 
composition of essential oils and the extraction of phenolic compounds are critical for the evaluation of their inhibitory activity and the cost-effectiveness of their application in meat-based products. Another way to increase the content of phenolic compounds in meat is via the incorporation of phenolic compounds in the diets of farm animals. This is a growing research field, currently challenged by knowledge gaps regarding the determination of the most effective phenolic compounds (type and concentration) and the most appropriate techniques to incorporate them in farm animal diets, without adversely affecting animal productivity, health, and welfare status.

In general, the demand for nutritious, functional, healthy and safe meat-based products is growing in modern societies, motivating the meat industry to develop new technologies. Among these technologies, the ones based on the addition of natural compounds such as fatty acids, minerals, vitamins, natural antioxidants, dietary fibers, probiotics or bioactive peptides are emerging [204-207]. Except for the antioxidant and anti-spoilage function of natural phenolic compounds, they also act beneficially for human health [208]. For example, flavonols have presented an anti-obesity effect [68,209], a protective effect against oxidative stress-induced neurotoxicity [210], and anti-diabetic [211] and potential anti-tumor activity [212]. Some natural phenolic compounds (e.g., date palm extract) have been found to exhibit an inhibitory function against the invasion and metastasis of cancer cells $[45,213]$. Another interesting aspect for public health is the fact that their antimicrobial action renders them promising alternatives to chemical additives and synthetic antimicrobials and, thereby, useful tools against the development of antibiotic resistance.

\section{Conclusions}

Despite the numerous in vitro and in situ studies demonstrating the beneficial effects of natural phenolic compounds against meat oxidation, spoilage, and foodborne pathogens, wide application and commercialization in the meat industry has not been yet achieved. Major obstacles are still the scarcity of a legislative framework, the large variety of meat-based products and targeted pathogens, and, in many cases, the limited number of case-specific application protocols and the questionable efficiency of those applied. The immediate establishment of a legislative framework for the use and assessment of natural phenolic compounds in meat-based products is a crucial prerequisite towards their massive application in meat industry and for the consumers' acceptability. Regardless of direct or indirect applications of phenolic compounds in meat systems, their effectiveness is neither universally accepted nor unquestionable. Instead, it is defined in a case-by-case manner, taking into account the phenolic compound itself, the meat-based product and the targeted microorganisms. In any case, real-world, in situ testing of these compounds is of paramount importance to verify their functionality and significance for the meat industry. Nano-encapsulation of the phenolic compounds in active packaging systems is a state-of-the-art technology with, though, limited in-depth studies regarding possible adverse effects on human health and the environment. Also, natural phenolic compounds and other natural antioxidant and antimicrobial substances could be jointly tested for the production of novel commercial food additives that will facilitate meat quality and safety assurance. Furthermore, the existence of synergistic activity between natural phenolic compounds and other preservation methods (e.g., high pressure processing) need to be investigated to achieve the optimum outcomes with the minimum effects on the organoleptic traits of meat. In the future natural phenolic compounds are expected to constitute an innovative tool integrated into meat systems to satisfy the ever-increasing demands for natural, quality, safe, and healthy food.

Author Contributions: Conceptualization, A.I.K., A.I.G., I.B. and T.L. Literature data collection, A.I.K. and T.L. Writing—original draft, A.I.K. and A.I.G. Writing-review and editing, T.L. and I.B. Supervision: A.I.G. and I.B. Project administration: A.I.G. Funding acquisition: A.I.G. All authors have read and agreed to the published version of the manuscript.

Funding: This review was funded by the Agricultural Cooperative "Agrinio Union" within the Regional Operational Program “Western Greece 2014-2020-RIS3," Project code: MIS-5040306.

Conflicts of Interest: The authors declare no conflict of interest. 


\section{References}

1. Schonfeldt, H.C.; Hall, N.G. Dietary protein quality and malnutrition in Africa. Br. J. Nutr. 2012, 108, s69-s76. [CrossRef] [PubMed]

2. Doulgeraki, A.I.; Ercolini, D.; Villani, F.; Nychas, G.E. Spoilage microbiota associated to the storage of raw meat in different conditions. Int. J. Food Microbiol. 2012, 157, 130-141. [CrossRef] [PubMed]

3. Chen, J.H.; Ren, Y.; Seow, J.; Liu, T.; Bang, W.S.; Yuk, H.G. Intervention Technologies for Ensuring Microbiological Safety of Meat: Current and Future Trends. Compr. Rev. Food Sci. Food Saf. 2012, 11, 119-132. [CrossRef]

4. FAO. Global food losses and food waste-extent, causes and prevention; FAO: Rome, Italy, 2011. Available online: http://www.fao.org/docrep/014/mb060e/mb060e.pdf (accessed on 15 April 2020).

5. FAO. Food Wastage Footprint. Available online: http://www.fao.org/3/i3347e/i3347e.pdf (accessed on 15 April 2020).

6. Niyonzima, E.; Ongol, M.P.; Kimonyo, A.; Sindic, M. Risk factors and control measures for bacterial contamination in the Bovine meat chain: A review on Salmonella and pathogenic E. coli. J. Food Res. 2015, 4, 98-121. [CrossRef]

7. Burgess, C.M.; Rivas, L.; McDonnell, M.J.; Duffy, G. Biocontrol of pathogens in the meat chain. In Meat Biotechnology; Toldra, F., Ed.; Springer: New York, NY, USA, 2008.

8. Saucier, L. Microbial spoilage, quality and safety within the context of meat sustainability. Meat Sci. 2016, 120, 78-84. [CrossRef]

9. Regulation (EC) No 852/2004 of the European Parliament and of the Council of 29 April 2004 on the hygiene of foodstuffs. Off. J. Eur. Union 2004, L 139, 1-23.

10. Gassara, F.; Kouassi, A.P.; Brar, S.K.; Belkacemi, K. Green alternatives to nitrates and nitrites in meat-based products-A Review. Crit. Rev. Food Sci. Nutr. 2016, 56, 2133-2148. [CrossRef]

11. Huffman, R.D. Current and future technologies for the decontamination of carcasses and fresh meat. Meat Sci. 2002, 62, 285-294. [CrossRef]

12. Aymerich, T.; Picouet, P.A.; Monfort, J.M. MEAT Decontamination technologies for meat products. Meat Sci. 2008, 78, 114-129. [CrossRef]

13. Lucera, A.; Costa, C.; Conte, A.; Del Nobile, M.A. Food applications of natural antimicrobial compounds. Front. Microbiol. 2012, 3, 1-13. [CrossRef]

14. Veneziani, G.; Novelli, E.; Esposto, S.; Taticchi, A.; Servili, M. Chapter 11-Applications of recovered bioactive compounds in food products. In Olive Mill Waste: Recent Advances for Sustainable Management; Galanakis, C.M., Ed.; Academic Press: London, UK, 2017; pp. 231-253.

15. Aminzare, M.; Hashemi, M.; Ansarian, E.; Bimkar, M.; Azar, H.H.; Mehrasbi, M.R.; Daneshamooz, S.; Raeisi, M.; Jannat, B.; Afshari, A. Using Natural Antioxidants in Meat and Meat Products as Preservatives: A Review. Adv. Anim. Vet. Sci. 2019, 7, 417-426. [CrossRef]

16. Regulation (EC) No 853/2004 of the European Parliament and of the Council of 29 April 2004 laying down specific hygiene rules for food of animal origin. Off. J. Eur. Union 2004, L 139, 55-205.

17. Fernandes, R.D.P.; Trindade, M.A.; de Melo, M.P. Natural antioxidants and food applications: Healthy Perspectives. In Handbook of Food Bioengineering, Alternative and Replacement Foods; Holban, A.M., Grumezescu, A.M., Eds.; Academic Press: London, UK, 2018; pp. 31-64.

18. Brewer, M.S. Natural antioxidants: Sources, compounds, mechanisms of action, and potential applications. Compr. Rev. Food Sci. Food Saf. 2011, 10, 221-247. [CrossRef]

19. Soladoye, O.P.; Juárez, M.L.; Aalhus, J.L.; Shand, P.; Estévez, M. Protein oxidation in processed meat: Mechanisms and potential implications on human health. Compr. Rev. Food Sci. Food Saf. 2015, 14, 106-122. [CrossRef]

20. Estévez, M. Protein carbonyls in meat systems: A review. Meat Sci. 2011, 89, 259-279. [CrossRef]

21. Maqsood, S.; Benjakul, S.; Abushelaibi, A.; Alam, A. Phenolic compounds and plant phenolic extracts as natural antioxidants in prevention of lipid oxidation in seafood: A detailed review. Compr. Rev. Food Sci. Food Saf. 2014, 13, 1125-1140. [CrossRef]

22. O'Brien, S.J. The public health impact of food-related illness. Curr. Opin. Infect. Dis. 2012, 25, 537-545. [CrossRef] 
23. Mead, P.S.; Slutsker, L.; Dietz, V.; Mccaig, L.F.; Bresee, J.S.; Shapiro, C.; Griffin, P.M.; Tauxe, R.V. Food-related illness and death in the United States. Emerg. Infect. Dis. 1999, 5, 607-625. [CrossRef]

24. Scallan, E.; Hoekstra, R.M.; Angulo, F.J.; Tauxe, R.V.; Widdowson, M.A.; Roy, S.L.; Jones, J.L.; Griffin, P.M. Foodborne illness acquired in the United States-Major pathogens. Emerg. Infect. Dis. 2011, 17, 7-15. [CrossRef]

25. Chizzolini, R.; Novelli, E.; Zanardi, E. Oxidation in traditional Mediterranean meat products. Meat Sci. 1998, 49, S87-S99. [CrossRef]

26. Kanner, J. Dietary advanced lipid oxidation endproducts are risk factors to human health. Mol. Nutr. Food Res. 2007, 51, 1094-1101. [CrossRef] [PubMed]

27. European Food Safety Authority and European Centre for Disease Prevention and Control (EFSA and ECDC). The European Union One Health 2018 Zoonoses Report. EFSA J. 2019, 17, e05926. [CrossRef]

28. Dewey-Mattia, D.; Kisselburgh, H. Surveillance for Foodborne Disease Outbreaks-United States, 2017: Annual Report; Centers for Disease Control and Prevention (CDC): Atlanta, GA, USA, 2017; pp. 1-10.

29. Dewey-Mattia, D.; Manikonda, K.; Hall, A.J.; Wise, M.E.; Crowe, S.J. Surveillance for Foodborne Disease Outbreaks-United States, 2009-2015; Center for Surveillance, Epidemiology, and Laboratory Services, Centers for Disease Control and Prevention (CDC): Atlanta, GA, USA, 2018; pp. 1-11.

30. Parr, A.J.; Bolwell, G.P. Phenols in the plant and in man. The potential for possible nutritional enhancement of the diet by modifying the phenols content or profile. J. Sci. Food Agric. 2000, 80, 985-1012. [CrossRef]

31. De la Rosa, L.A.; Moreno-Escamilla, J.O.; Rodrigo-García, J.; Alvarez-Parrilla, E. Phenolic compounds. In Postharvest Physiology and Biochemistry of Fruits and Vegetables; Yahia, E.M., Ed.; Woodhead Publishing: Duxford, UK, 2018; pp. 253-271.

32. Gan, R.-Y.; Chan, C.-L.; Yang, Q.-Q.; Li, H.-B.; Zhang, D.; Ge, Y.-Y.; Gunaratne, A.; Ge, J.; Corke, H. Bioactive compounds and beneficial functions of sprouted grains. In Sprouted Grains; Feng, H., Nemzer, B., DeVries, J.W., Eds.; AACC International Press: Duxford, UK, 2019; pp. 191-246.

33. Lourdes Reis Giada, M. Food phenolic compounds: Main classes, sources and their antioxidant power. In Oxidative Stress and Chronic Degenerative Diseases-A Role for Antioxidants; Morales-Gonzalez, J.A., Ed.; IntechOpen: London, UK, 2013; pp. 87-112.

34. Hintz, T.; Matthews, K.K.; Di, R. The use of plant antimicrobial compounds for food preservation. Biomed. Res. Int. 2015. [CrossRef] [PubMed]

35. Lafay, S.; Gil-Izquierdo, A. Bioavailability of phenolic acids. Phytochem. Rev. 2008, 7, 301-311. [CrossRef]

36. Falowo, A.B.; Fayemi, P.O.; Muchenje, V. Natural antioxidants against lipid-protein oxidative deterioration in meat and meat products: A review. Food Res. Int. 2014, 64, 171-181. [CrossRef]

37. Jayasena, D.D.; Jo, C. Essential oils as potential antimicrobial agents in meat and meat products: A review. Trends Food Sci. Technol. 2013, 34, 96-108. [CrossRef]

38. Pateiro, M.; Barba, F.J.; Domínguez, R.; Sant' Ana, A.S.; Khaneghahc, A.M.; Mohsen, G.; Gómez, B.; Lorenzo, J.M. Essential oils as natural additives to prevent oxidation reactions in meat and meat products: A review. Food Res. Int. 2018, 113, 156-166. [CrossRef]

39. Hyldgaard, M.; Mygind, T.; Meyer, R.L.; Debabov, D. Essential oils in food preservation: Mode of action, synergies, and interactions with food matrix components. Front. Microbiol. 2012, 3, 1-24. [CrossRef]

40. Christaki, E.; Bonos, E.; Giannenas, I.; Florou-paneri, P. Aromatic plants as a source of bioactive compounds. Agriculture 2012, 2, 228-243. [CrossRef]

41. Parke, D.V.; Lewis, D.F.V. Safety aspects of food preservatives. Food Addit. Contam. 1992, 9, 561-577. [CrossRef] [PubMed]

42. Karre, L.; Lopez, K.; Getty, K.J.K. Natural antioxidants in meat and poultry products. Meat Sci. 2013, 94, 220-227. [CrossRef] [PubMed]

43. Dwivedi, S.; Prajapati, P.; Vyas, N.; Malviya, S.; Kharia, A. A review on food preservation: Methods, harmful effects and better alternatives. Asian J. Pharm. Pharmacol. 2017, 3, 193-199.

44. Tesoriere, L.; Butera, D.; Gentile, C.; Livrea, M.A. Bioactive components of caper (Capparis spinosa L.) from Sicily and antioxidant effects in a red meat simulated gastric digestion. J. Agric. Food Chem. 2007, 55, 8465-8471. [CrossRef] [PubMed]

45. Weng, C.; Yen, G. Chemopreventive effects of dietary phytochemicals against cancer invasion and metastasis: Phenolic acids, monophenol, polyphenol, and their derivatives. Cancer Treat. Rev. 2012, 38, 76-87. [CrossRef] [PubMed] 
46. Embuscado, M.E. Spices and herbs: Natural sources of antioxidants-A mini review. J. Funct. Foods 2015, 18, 811-819. [CrossRef]

47. Huang, B.; He, J.; Ban, X.; Zeng, H.; Yao, X.; Wang, Y. Antioxidant activity of bovine and porcine meat treated with extracts from edible lotus (Nelumbo nucifera) rhizome knot and leaf. Meat Sci. 2011, 87, 46-53. [CrossRef]

48. Lorenzo, J.M.; Batlle, R.; Gómez, M. Extension of the shelf-life of foal meat with two antioxidant active packaging systems. LWT Food Sci. Technol. 2014, 59, 181-188. [CrossRef]

49. Haak, L.; Raes, K.; Smet, S. De Effect of plant phenolics, tocopherol and ascorbic acid on oxidative stability of pork patties. J. Sci. Food. Agric. 2009, 1360-1365. [CrossRef]

50. Lorenzo, J.M.; Sineiro, J.; Amado, I.R.; Franco, D. Influence of natural extracts on the shelf life of modified atmosphere-packaged pork patties. Meat Sci. 2014, 96, 526-534. [CrossRef]

51. Van Cuong, T.; Chin, K.B. Evaluation of Cudrania tricuspidata leaves on antioxidant activities and physicochemical properties of pork patties. Korean J. Food Sci. Anim. Resour. 2018, 38, 889-900. [CrossRef] [PubMed]

52. Jia, N.; Kong, B.; Liu, Q.; Diao, X.; Xia, X. Antioxidant activity of black currant (Ribes nigrum L.) extract and its inhibitory effect on lipid and protein oxidation of pork patties during chilled storage. Meat Sci. 2012, 91, 533-539. [CrossRef] [PubMed]

53. Jiang, J.; Zhang, X.; True, A.D.; Zhou, L.; Xiong, Y.L. Inhibition of lipid oxidation and rancidity in precooked pork patties by radical-scavenging licorice (Glycyrrhiza glabra) Extract. J. Food Sci. 2013, 78, C1686-C1694. [CrossRef] [PubMed]

54. Qin, Y.Y.; Yang, J.Y.; Lu, H.B.; Wang, S.S.; Yang, J.; Yang, X.C.; Chai, M.; Li, L.; Cao, J.X. Effect of chitosan film incorporated with tea polyphenol on quality and shelf life of pork meat patties. Int. J. Biol. Macromol. 2013, 61, 312-316. [CrossRef]

55. Lara, M.S.; Gutierrez, J.I.; Timón, M.; Andrés, A.I. Evaluation of two natural extracts (Rosmarinus officinalis L. and Melissa officinalis L.) as antioxidants in cooked pork patties packed in MAP. Meat Sci. 2011, 88, 481-488. [CrossRef]

56. Carpenter, R.; O'Grady, M.N.; O'Callaghan, Y.C.; O’Brien, N.M.; Kerry, J.P. Evaluation of the antioxidant potential of grape seed and bearberry extracts in raw and cooked pork. Meat Sci. 2007, 76, 604-610. [CrossRef]

57. Ganhão, R.; Estévez, M.; Armenteros, M.; Morcuende, D. Mediterranean berries as inhibitors of lipid oxidation in porcine burger patties subjected to cooking and chilled storage. J. Integr. Agric. 2013, 12, 1982-1992. [CrossRef]

58. Kobus-Cisowska, J.; Flaczyk, E.; Rudzi, M.; Kmiecik, D. Antioxidant properties of extracts from Ginkgo biloba leaves in meatballs. Meat Sci. 2014, 97, 174-180. [CrossRef]

59. Pateiro, M.; Lorenzo, J.M.; Amado, I.R.; Franco, D. Effect of addition of green tea, chestnut and grape extract on the shelf-life of pig liver pâté. Food Chem. 2014, 147, 386-394. [CrossRef]

60. Martín-Sánchez, A.M.; Ciro-Gómez, G.; Sayas, E.; Vilella-Esplá, J.; Ben-Abda, J.; Pérez-Alvarez, J.Á. Date palm by-products as a new ingredient for the meat industry: Application to pork liver pâté. Meat Sci. 2013, 93, 880-887. [CrossRef]

61. Martin-Sanchez, A.; Ciro-Gomez, G.; Zapata-Montoya, J.; Vilella-Espla, J.; Perez-Alvarez, J.; Sayas-Barberá, E. Effect of date palm coproducts and annatto extract on lipid oxidation and microbial quality in a pork liver pâté. J. Food Sci. 2014, 79, 2301-2307. [CrossRef] [PubMed]

62. Hayes, J.E.; Stepanyan, V.; Allen, P.; Grady, M.N.O.; Kerry, J.P. Evaluation of the effects of selected plant-derived nutraceuticals on the quality and shelf-life stability of raw and cooked pork sausages. LWT Food Sci. Technol. 2011, 44, 164-172. [CrossRef]

63. Lorenzo, J.M.; González-rodríguez, R.M.; Sánchez, M.; Amado, I.R.; Franco, D. Effects of natural (grape seed and chestnut extract) and synthetic antioxidants (buthylatedhydroxytoluene, BHT) on the physical, chemical, microbiological and sensory characteristics of dry cured sausage "chorizo". J. Food Sci. 2013, 54, 611-620. [CrossRef]

64. Jayawardana, B.C.; Hirano, T.; Han, K.H.; Ishii, H.; Okada, T.; Shibayama, S.; Fukushima, M.; Sekikawa, M.; Shimada, K.I. Utilization of adzuki bean extract as a natural antioxidant in cured and uncured cooked pork sausages. Meat Sci. 2011, 89, 150-153. [CrossRef] [PubMed] 
65. De Almeida, P.L.; de Lima, S.N.; Costa, L.L.; de Oliveira, C.C.; Damasceno, K.A.; dos Santos, B.A.; Campagnol, P.C.B. Effect of jabuticaba peel extract on lipid oxidation, microbial stability and sensory properties of Bologna-type sausages during refrigerated storage. Meat Sci. 2015, 110, 9-14. [CrossRef] [PubMed]

66. Jongberg, S.; Tørngren, M.A.; Gunvig, A.; Skibsted, L.H.; Lund, M.N. Effect of green tea or rosemary extract on protein oxidation in Bologna type sausages prepared from oxidatively stressed pork. Meat Sci. 2013, 93, 538-546. [CrossRef]

67. Zhang, L.; Lin, Y.H.; Leng, X.J.; Huang, M.; Zhou, G.H. Effect of sage (Salvia officinalis) on the oxidative stability of Chinese-style sausage during refrigerated storage. Meat Sci. 2013, 95, 145-150. [CrossRef]

68. Qi, S.; Zhou, D. Lotus seed epicarp extract as potential antioxidant and anti-obesity additive in Chinese Cantonese Sausage. Meat Sci. 2013, 93, 257-262. [CrossRef]

69. Pil-Nam, S.; Park, K.M.; Kang, G.H.; Cho, S.H.; Park, B.Y.; Van-Ba, H. The impact of addition of shiitake on quality characteristics of frankfurter during refrigerated storage. LWT Food Sci. Technol. 2015, 62, 62-68. [CrossRef]

70. Rodrigues, A.S.; Kubota, E.H.; Giacomelli, C.; Alves, S.; Rodrigues, G.S.; Cezar, P.; Campagnol, B. Banana in florescences: A cheap raw material with great potential to be used as a natural antioxidant in meat products. Meat Sci. 2020, 161, 1-5. [CrossRef]

71. Wang, Y.; Li, F.; Zhuang, H.; Li, L.; Chen, X.; Zhang, J. Effects of plant polyphenols and $\alpha$-tocopherol on lipid oxidation, microbiological characteristics, and biogenic amines formation in dry-cured bacons. J. Food Sci. 2015, 80, 547-555. [CrossRef]

72. Armenteros, M.; Morcuende, D.; Ventanas, J.; Estévez, M. The application of natural antioxidants via brine injection protects Iberian cooked hams against lipid and protein oxidation. Meat Sci. 2016, 116, 253-259. [CrossRef] [PubMed]

73. Barbosa-Pereira, L.; Angulo, I.; Lagaron, J.M.; Paseiro-Losada, P.; Cruz, J.M. Development of new active packaging films containing bioactive nanocomposites. Innov. Food Sci. Emerg. Technol. 2014, 26, 310-318. [CrossRef]

74. Bermúdez-Oria, A.; Rodríguez-Gutiérrez, G.; Rubio-Senent, F.; Fernández-Prior, Á.; Fernández-Bolaños, J. Effect of edible pectin-fish gelatin films containing the olive antioxidants hydroxytyrosol and 3,4-dihydroxyphenylglycol on beef meat during refrigerated storage. Meat Sci. 2019, 148, 213-218. [CrossRef] [PubMed]

75. Kim, S.; Cho, A.R.; Han, J. Antioxidant and antimicrobial activities of leafy green vegetable extracts and their applications to meat product preservation. Food Control 2013, 29, 112-120. [CrossRef]

76. Zamuz, S.; López-Pedrouso, M.; Barba, F.J.; Lorenzo, J.M.; Domínguez, H.; Franco, D. Application of hull, bur and leaf chestnut extracts on the shelf-life of beef patties stored under MAP: Evaluation of their impact on physicochemical properties, lipid oxidation, antioxidant, and antimicrobial potential. Food Res. Int. 2018, 112, 263-273. [CrossRef]

77. García-Lomillo, J.; Gonzalez-SanJose, M.L.; Del Pino-García, R.; Ortega-Heras, M.; Muñiz-Rodríguez, P. Antioxidant effect of seasonings derived from wine pomace on lipid oxidation in refrigerated and frozen beef patties. LWT Food Sci. Technol. 2017, 77, 85-91. [CrossRef]

78. Akcan, T.; Estévez, M.; Serdaroğlu, M. Antioxidant protection of cooked meatballs during frozen storage by whey protein edible films with phytochemicals from Laurus nobilis L. and Salvia officinalis. LWT Food Sci. Technol. 2017, 77, 323-331. [CrossRef]

79. Turgut, S.S.; Işıkçı, F.; Soyer, A. Antioxidant activity of pomegranate peel extract on lipid and protein oxidation in beef meatballs during frozen storage. Meat Sci. 2017, 129, 111-119. [CrossRef]

80. Kulkarni, S.; Desantos, F.A.; Kattamuri, S.; Rossi, S.J.; Brewer, M.S. Effect of grape seed extract on oxidative, color and sensory stability of a pre-cooked, frozen, re-heated beef sausage model system. Meat Sci. 2011, 88, 139-144. [CrossRef]

81. Alirezalu, K.; Hesari, J.; Eskandari, M.H.; Valizadeh, H.; Sirousazar, M. Effect of green tea, stinging nettle and olive leaves extracts on the quality and shelf life stability of frankfurter type sausage. J. Food Process. Preserv. 2017, 41, e13100. [CrossRef]

82. Frasao, B.; Costa, M.; Silva, F.; Rodrigues, B.; Araujo, J.; Moreira, D.; Torrezan, R.; Id, C.C. Effect of pequi (Caryocar brasiliense) and jucara (Euterpe edulis) waste extract on oxidation process stability in broiler meat treated by UV-C. PLoS ONE 2018, 13, e0208306. [CrossRef] [PubMed] 
83. Biswas, A.K.; Beura, C.K.; Yadav, A.S.; Pandey, N.K.; Mendiratta, S.K.; Kataria, J.M. Influence of novel bioactive compounds from selected fruit by-products and plant materials on the quality and storability of microwave-assisted cooked poultry meat wafer during ambient temperature storage. LWT Food Sci. Technol. 2015, 62, 727-733. [CrossRef]

84. Naveena, B.M.; Sen, A.R.; Vaithiyanathan, S.; Babji, Y.; Kondaiah, N. Comparative efficacy of pomegranate juice, pomegranate rind powder extract and BHT as antioxidants in cooked chicken patties. Meat Sci. 2008, 80, 1304-1308. [CrossRef] [PubMed]

85. Andrés, A.I.; Petrón, M.J.; Adámez, J.D.; López, M.; Timón, M.L. Food by-products as potential antioxidant and antimicrobial additives in chill stored raw lamb patties. Meat Sci. 2017, 129, 62-70. [CrossRef]

86. Fernandes, R.P.P.; Trindade, M.A.; Tonin, F.G.; Pugine, S.M.P.; Lima, C.G.; Lorenzo, J.M.; Melo, M.P. De Evaluation of oxidative stability of lamb burger with Origanum vulgare extract. Food Chem. 2017, 233, 101-109. [CrossRef]

87. Fernandes, R.P.P.; Trindade, M.A.; Lorenzo, J.M.; Melo, M.P. De Assessment of the stability of sheep sausages with the addition of di ff erent concentrations of Origanum vulgare extract during storage. Meat Sci. 2018, 137, 244-257. [CrossRef]

88. Bozkurt, H. Utilization of natural antioxidants: Green tea extract and Thymbra spicata oil in Turkish dry-fermented sausage. Meat Sci. 2006, 73, 442-450. [CrossRef]

89. Šojić, B.; Tomović, V.; Kocić-Tanackov, S.; Škaljac, S.; Ikonić, P.; Džinić, N.; Živković, N.; Jokanović, M.; Tasić, T.; Kravić, S. Effect of nutmeg (Myristica fragrans) essential oil on the oxidative and microbial stability of cooked sausage during refrigerated storage. Food Control 2015, 54, 282-286. [CrossRef]

90. Lule, S.U.; Xia, W. Food phenolics, pros and cons: A review. Food. Rev. Int. 2005, 21, 367-388. [CrossRef]

91. Holley, R.A.; Patel, D. Improvement in shelf-life and safety of perishable foods by plant essential oils and smoke antimicrobials. Food Microbiol. 2005, 22, 273-292. [CrossRef]

92. He, M.; Wu, T.; Pan, S.; Xu, X. Antimicrobial mechanism of flavonoids against Escherichia coli ATCC 25922 by model membrane study. Appl. Surf. Sci. 2014, 305, 515-521. [CrossRef]

93. Rempe, C.S.; Burris, K.P.; Lenaghan, S.C.; Stewart, C.N. The potential of systems biology to discover antibacterial mechanisms of plant phenolics. Front. Microbiol. 2017, 8, 422. [CrossRef] [PubMed]

94. Pisoschi, A.M.; Pop, A.; Georgescu, C.; Turcuş, V.; Olah, N.K.; Mathe, E. An overview of natural antimicrobials role in food. Eur. J. Med. Chem. 2018, 143, 922-935. [CrossRef] [PubMed]

95. Trombetta, D.; Castelli, F.; Sarpietro, M.G.; Venuti, V.; Cristani, M.; Daniele, C.; Saija, A.; Mazzanti, G.; Bisignano, G. Mechanisms of antibacterial action of three monoterpenes. Antimicrob. Agents Chemother. 2005, 49, 2474-2478. [CrossRef] [PubMed]

96. Devi, K.P.; Nisha, S.A.; Sakthivel, R.; Pandian, S.K. Eugenol (an essential oil of clove) acts as an antibacterial agent against Salmonella typhi by disrupting the cellular membrane. J. Ethnopharmacol. 2010, 130, 107-115. [CrossRef] [PubMed]

97. Burt, S. Essential oils: Their antibacterial properties and potential applications in foods-A review. Int. J. Food Microbiol. 2004, 94, 223-253. [CrossRef] [PubMed]

98. Gill, A.O.; Holley, R.A. Inhibition of membrane bound ATPases of Escherichia coli and Listeria monocytogenes by plant oil aromatics. Int. J. Food Microbiol. 2006, 111, 170-174. [CrossRef]

99. Ultee, A.; Bennik, M.H.J.; Moezelaar, R. The phenolic hydroxyl group of carvacrol is essential for action against the food-borne pathogen Bacillus cereus. Appl. Environ. Microbiol. 2002, 68, 1561-1568. [CrossRef]

100. Lou, Z.; Wang, H.; Rao, S.; Sun, J.; Ma, C.; Li, J. P-Coumaric acid kills bacteria through dual damage mechanisms. Food Control 2012, 25, 550-554. [CrossRef]

101. Carraro, L.; Fasolato, L.; Montemurro, F.; Martino, M.E.; Balzan, S.; Servili, M.; Novelli, E.; Cardazzo, B. Polyphenols from olive mill waste affect biofilm formation and motility in Escherichia coliK-12. Microb. Biotechnol. 2014, 7, 265-275. [CrossRef] [PubMed]

102. Wagle, B.R.; Upadhyay, A.; Shrestha, S.; Arsi, K.; Upadhyaya, I.; Donoghue, A.M.; Donoghue, D.J. Pectin or chitosan coating fortified with eugenol reduces Campylobacter jejuni on chicken wingettes and modulates expression of critical survival genes. Poult. Sci. 2019, 98, 1461-1471. [CrossRef] [PubMed]

103. Ahn, J.; Grun, I.U.; Mustapha, A. Antimicrobial and antioxidant activities of natural extracts in vitro and in ground beef. J. Food Prot. 2004, 67, 148-155. [CrossRef] [PubMed]

104. Lin, Y.T.; Labbe, R.G.; Shetty, K. Inhibition of Listeria monocytogenes in fish and meat systems by use of oregano and cranberry phytochemical synergies. Appl. Environ. Microbiol. 2004, 70, 5672-5678. [CrossRef] 
105. Gutierrez, J.; Bourke, P. Antimicrobial activity of plant essential oils using food model media: Efficacy, synergistic potential and interactions with food components. Food Microbiol. 2009, 26, 142-150. [CrossRef]

106. Tajkarimi, M.M.; Ibrahim, S.A.; Cliver, D.O. Antimicrobial herb and spice compounds in food. Food Control 2010, 21, 1199-1218. [CrossRef]

107. Friedman, M.; Jürgens, H.S. Effect of $\mathrm{pH}$ on the stability of plant phenolic compounds. J. Agric. Food Chem. 2000, 48, 2101-2110. [CrossRef]

108. Larson, A.E.; Yu, R.R.Y.; Lee, O.A.; Haas, G.J.; Johnsona, E.A. Antimicrobial activity of hop extracts against Listeria monocytogenes in media and in food. Food Microbiol. 1996, 33, 195-207. [CrossRef]

109. Ozdal, T.; Capanoglu, E.; Altay, F. A review on protein-phenolic interactions and associated changes. Food Res. Int. 2013, 51, 954-970. [CrossRef]

110. Gill, A.O.; Delaquis, P.; Russo, P.; Holley, R.A. Evaluation of antilisterial action of cilantro oil on vacuum packed ham. Int. J. Food Microbiol. 2002, 73, 83-92. [CrossRef]

111. Delaquis, P.J.; Stanich, K.; Girard, B.; Mazza, G. Antimicrobial activity of individual and mixed fractions of dill, cilantro, coriander and eucalyptus essential oils. Int. J. Food Microbiol. 2002, 74, 101-109. [CrossRef]

112. Gallucci, M.N.; Oliva, M.; Casero, C.; Dambolena, J.; Luna, A.; Zygadlo, J.; Demo, M. Antimicrobial combined action of terpenes against the food-borne microorganisms Escherichia coli, Staphylococcus aureus and Bacillus cereus. Flavour Fragr. J. 2009, 24, 348-354. [CrossRef]

113. Apostolidis, E.; Kwon, Y.; Shetty, K. Inhibition of Listeria monocytogenes by oregano, cranberry and sodium lactate combination in broth and cooked ground beef systems and likely mode of action through proline metabolism. Int. J. Food Microbiol. 2008, 128, 317-324. [CrossRef] [PubMed]

114. Cho, Y.S.; Schiller, N.L.; Oh, K.H. Antibacterial effects of green tea polyphenols on clinical isolates of methicillin-resistant Staphylococcus aureus. Curr. Microbiol. 2008, 57, 542-546. [CrossRef]

115. Neyestani, T.R.; Khalaji, N.; Gharavi, A. Selective microbiologic effects of tea extract on certain antibiotics against Escherichia coli in vitro. J. Altern. Complement. Med. 2007, 13, 1119-1124. [CrossRef]

116. Lee, Y.S.; Han, C.H.; Kang, S.H.; Lee, S.-J.; Kim, S.W.; Shin, O.R.; Sim, Y.-C.; Lee, S.-J.; Cho, Y.-H. Synergistic effect between catechin and ciprofloxacin on chronic bacterial prostatitis rat model. Int. J. Urol. 2005, 12, 383-389. [CrossRef]

117. Oh, E.; Jeon, B. Synergistic anti-Campylobacter jejuni activity of fluoroquinolone and macrolide antibiotics with phenolic compounds. Front. Microbiol. 2015, 6, 1-9. [CrossRef]

118. Chusri, S.; Villanueva, I.; Voravuthikunchai, S.P.; Davies, J. Enhancing antibiotic activity: A strategy to control Acinetobacter infections. J. Antimicrob. Chemother. 2009, 64, 1203-1211. [CrossRef]

119. Alves, M.J.; Ferreira, I.C.F.R.; Froufe, H.J.C.; Abreu, R.M.V.; Martins, A.; Pintado, M. Antimicrobial activity of phenolic compounds identified in wild mushrooms, SAR analysis and docking studies. J. Appl. Microbiol. 2013, 115, 346-357. [CrossRef]

120. Vaquero, M.J.R.; Alberto, M.R.; de Nadra, M.C.M. Antibacterial effect of phenolic compounds from different wines. Food Control 2007, 18, 93-101. [CrossRef]

121. Gutiérrez-Larraínzar, M.; Rúa, J.; Caro, I.; de Castro, C.; de Arriaga, D.; García-Armesto, M.R.; del Valle, P. Evaluation of antimicrobial and antioxidant activities of natural phenolic compounds against foodborne pathogens and spoilage bacteria. Food Control 2012, 26, 555-563. [CrossRef]

122. Teke, G.N.; Kuiate, J.R.; Kueté, V.; Teponno, R.B.; Tapondjou, L.A.; Tane, P.; Giacinti, G.; Vilarem, G. Bio-guided isolation of potential antimicrobial and antioxidant agents from the stem bark of Trilepisium madagascariense. South African J. Bot. 2011, 77, 319-327. [CrossRef]

123. Cetin-Karaca, H.; Newman, M.C. Antimicrobial efficacy of plant phenolic compounds against Salmonella and Escherichia Coli. Food Biosci. 2015, 11, 8-16. [CrossRef]

124. Taguri, T.; Tanaka, T.; Kouno, I. Antimicrobial activity of 10 different plant polyphenols against bacteria causing food-borne disease. Biol. Pharm. Bull. 2004, 27, 1965-1969. [CrossRef] [PubMed]

125. Orhan, D.D.; Özçelik, B.; Özgen, S.; Ergun, F. Antibacterial, antifungal, and antiviral activities of some flavonoids. Microbiol. Res. 2010, 165, 496-504. [CrossRef] [PubMed]

126. Rozès, N.; Peres, C. Effects of phenolic compounds on the growth and the fatty acid composition of Lactobacillus plantarum. Appl. Microbiol. Biotechnol. 1998, 49, 108-111. [CrossRef]

127. Nitiema, L.W.; Savadogo, A.; Simpore, J.; Dianou, D.; Traore, A.S. In vitro antimicrobial activity of some phenolic compounds (coumarin and quercetin) against gastroenteritis bacterial strains. Int. J. Microbiol. Res. 2012, 3, 183-187. [CrossRef] 
128. Fernández, M.A.; García, M.D.; Sáenz, M.T. Antibacterial activity of the phenolic acids fractions of Scrophularia frutescens and Scrophularia sambucifolia. J. Ethnopharmacol. 1996, 53, 11-14. [CrossRef]

129. Carraturo, A. Antibacterial activity of phenolic compounds derived from Ginkgo biloba sarcotestas against food-borne pathogens. Br. Microbiol. Res. J. 2014, 4, 18-27. [CrossRef]

130. Fasolato, L.; Cardazzo, B.; Balzan, S.; Carraro, L.; Taticchi, A.; Montemurro, F.; Novelli, E. Minimum bactericidal concentration of phenols extracted from oil vegetation water on spoilers, starters and food-borne bacteria. Ital. J. Food Saf. 2015, 4, 4-6. [CrossRef]

131. Roila, R.; Ranucci, D.; Valiani, A.; Galarini, R.; Servili, M.; Branciari, R. Antimicrobial and anti-biofilm activity of olive oil. Acta Sci. Pol. Technol. Aliment. 2019, 18, 43-52. [CrossRef] [PubMed]

132. Liaqat, A.; Zahoor, T.; Atif, M.; Muhammad, R. Characterization and antimicrobial potential of bioactive components of sonicated extract from garlic (Allium sativum) against foodborne pathogens. J. Food Process. Preserv. 2019, 43, 1-8. [CrossRef]

133. Rivera Calo, J.; Crandall, P.G.; Bryan, C.A.O.; Ricke, S.C. Essential oils as antimicrobials in food systems e-A review. Food Control 2015, 54, 111-119. [CrossRef]

134. Puupponen-Pimia, R.; Nohynek, L.; Meier, C.; Kahkonen, M.; Heinonen, M.; Hopia, A.; Oksman-Caldentey, K. Antimicrobial properties of phenolic compounds from berries. J. Appl. Microbiol. 2001, 90, 494-507. [CrossRef] [PubMed]

135. Ambrosio, C.M.S.; Contreras-Castillo, C.J.; Da Gloria, E.M. In vitro mechanism of antibacterial action of a citrus essential oil on an enterotoxigenic Escherichia coli and Lactobacillus rhamnosus. J. Appl. Microbiol. 2020. [CrossRef]

136. Georgantelis, D.; Ambrosiadis, I.; Katikou, P.; Blekas, G.; Georgakis, S. Effect of rosemary extract, chitosan and $\alpha$-tocopherol on microbiological parameters and lipid oxidation of fresh pork sausages stored at $4{ }^{\circ} \mathrm{C}$. Meat Sci. 2007, 76, 172-181. [CrossRef]

137. Chaves-López, C.; Serio, A.; Mazzarrino, G.; Martuscelli, M.; Scarpone, E.; Paparella, A. Control of household myco $\mathrm{fl}$ ora in fermented sausages using phenolic fractions from olive mill wastewaters. Int. J. Food Microbiol. 2015, 207, 49-56. [CrossRef]

138. Fasolato, L.; Carraro, L.; Facco, P.; Cardazzo, B.; Balzan, S.; Taticchi, A.; Andrea, N.; Montemurro, F.; Elena, M.; Di, G.; et al. Agricultural by-products with bioactive effects: A multivariate approach to evaluate microbial and physicochemical changes in a fresh pork sausage enriched with phenolic compounds from olive vegetation water. Int. J. Food Microbiol. 2016, 228, 34-43. [CrossRef]

139. Busatta, C.; Mossi, A.J.; Regina, M.; Rodrigues, A.; Cansian, R.L.; de Oliveira, J.V. Evaluation of origanum vulgare essential oil as antimicrobial agent in sausage. Brazilian J. Microbiol. 2007, 38, 610-616. [CrossRef]

140. Busatta, C.; Vidal, R.S.; Popiolski, A.S.; Mossi, A.J.; Dariva, C.; Rodrigues, M.R.A. Application of Origanum majorana L. essential oil as an antimicrobial agent in sausage. Food Microbiol. 2008, 25, 207-211. [CrossRef]

141. Hayrapetyan, H.; Hazeleger, W.C.; Beumer, R.R. Inhibition of Listeria monocytogenes by pomegranate (Punica granatum) peel extract in meat paté at different temperatures. Food Control 2012, 23, 66-72. [CrossRef]

142. Ravishankar, S.; Zhu, L.; Olsen, C.; McHugh, T.; Friedman, M. Edible apple film wraps containing plant antimicrobials inactivate foodborne pathogens on meat and poultry products. J. Food Microbiol. Saf. 2009, 74, 440-445. [CrossRef] [PubMed]

143. Tamkute, L.; Gil, B.M.; Carbadillo, J.R.; Pukalskiene, M.; Venskutonis, P.R. Effect of cranberry pomace extracts isolated by pressurized ethanol and water on the inhibition of food pathogenic/spoilage bacteria and the quality of pork products. Food Res. Int. 2019, 120, 38-51. [CrossRef] [PubMed]

144. Soares, J.M.; Franklin, P.; Maria, B.; Puton, S.; Brustolin, A.P.; Cansian, R.L.; Dallago, R.M.; Valduga, E. Antimicrobial and antioxidant activity of liquid smoke and its potential application to bacon. Innov. Food Sci. Emerg. Technol. 2016, 38, 189-197. [CrossRef]

145. De Souza, E.L.; de Barros, J.C.; da Conceição, M.L.; Gomes Neto, N.J.; da Costa, A.C.V. Combined application of Origanum vulgare L. essential oil and acetic acid for controlling the growth of Staphylococcus aureus in foods. Braz. J. Microbiol. 2009, 40, 387-393. [CrossRef]

146. Tremonte, P.; Sorrentino, E.; Succi, M.; Tipaldi, L.; Pannella, G.; Mendiola, J.A.; Di Renzo, T.; Reale, A.; Coppola, R. Antimicrobial Effect of Malpighia Punicifolia and Extension of Water Buffalo Steak Shelf-Life. J. Food Sci. 2016, 81, 97-105. [CrossRef] 
147. Hayouni, E.; Chraief, I.; Abedrabba, M.; Bouix, M.; Leveau, J.; Mohammed, H.; Hamdi, M. Tunisian Salvia officinalis L. and Schinus molle L. essential oils: Their chemical compositions and their preservative effects against Salmonella inoculated in minced beef meat. Int. J. Food Microbiol. 2008, 125, 242-251. [CrossRef]

148. Palmeri, R.; Parafati, L.; Restuccia, C.; Fallico, B. Application of prickly pear fruit extract to improve domestic shelf life, quality and microbial safety of sliced beef. Food Chem. Toxicol. 2018, 118, 355-360. [CrossRef]

149. Djenane, D.; Yangüela, J.; Montañés, L.; Djerbal, M.; Roncalés, P. Antimicrobial activity of Pistacia lentiscus and Satureja montana essential oils against Listeria monocytogenes CECT 935 using laboratory media: Efficacy and synergistic potential in minced beef. Food Control 2011, 22, 1046-1053. [CrossRef]

150. Mhalla, D.; Bouaziz, A.; Ennouri, K.; Chawech, R.; Smaoui, S.; Jarraya, R.; Tounsi, S.; Trigui, M. Antimicrobial activity and bioguided fractionation of Rumex tingitanus extracts for meat preservation. Meat Sci. 2017, 125, 22-29. [CrossRef]

151. Del Nobile, M.; Conte, A.; Cannarsi, M.; Sinigaglia, M. Strategies for prolonging the shelf life of minced beef patties. J. Food Saf. 2009, 29, 14-25. [CrossRef]

152. García-Lomillo, J.; González-Sanjosé, M.L.; Del Pino-García, R.; Rivero-Pérez, M.D.; Muñiz-Rodríguez, P. Alternative natural seasoning to improve the microbial stability of low-salt beef patties. Food Chem. 2017, 227, 122-128. [CrossRef] [PubMed]

153. Sagdic, O.; Ozturk, I.; Yilmaz, M.T.; Yetim, H. Effect of grape pomace extracts obtained from different grape varieties on microbial quality of beef patty. J. Food Sci. 2011, 76, 515-521. [CrossRef] [PubMed]

154. Ekici, L.; Ozturk, I.; Karaman, S.; Caliskan, O.; Tornuk, F.; Sagdic, O.; Yetim, H. Effects of black carrot concentrate on some physicochemical, textural, bioactive, aroma and sensory properties of sucuk, a traditional Turkish dry-fermented sausage. LWT Food Sci. Technol. 2015, 62, 718-726. [CrossRef]

155. Burt, S.A.; Fledderman, M.J.; Haagsman, H.P.; Van Knapen, F.; Veldhuizen, E.J.A. Inhibition of Salmonella enterica serotype Enteritidis on agar and raw chicken by carvacrol vapour. Int. J. Food Microbiol. 2007, 119, 346-350. [CrossRef]

156. Chouliara, E.; Karatapanis, A.; Savvaidis, I.N.; Kontominas, M.G.Ã. Combined effect of oregano essential oil and modified atmosphere packaging on shelf-life extension of fresh chicken breast meat, stored at $4{ }^{\circ} \mathrm{C}$. Food Microbiol. 2007, 24, 607-617. [CrossRef]

157. Wafa, B.A.; Makni, M.; Ammar, S.; Khannous, L.; Ben Hassana, A.; Bouaziz, M.; Es-Safi, N.E.; Gdoura, R. Antimicrobial effect of the Tunisian Nana variety Punica granatum L. extracts against Salmonella enterica (serovars Kentucky and Enteritidis) isolated from chicken meat and phenolic composition of its peel extract. Int. J. Food Microbiol. 2017, 241, 123-131. [CrossRef]

158. Muppalla, S.R.; Chawla, S. Effect of gum Arabic-polyvinyl alcohol films containing seed cover extract of zanthoxylum rhetsa on shelf life of refrigerated ground chicken meat. J. Food Saf. 2018, 38, 1-10. [CrossRef]

159. Mulla, M.; Ahmed, J.; Al-attar, H.; Castro-aguirre, E.; Ali, Y.; Auras, R. Antimicrobial efficacy of clove essential oil infused into chemically modified LLDPE film for chicken meat packaging. Food Control 2017, 73, 663-671. [CrossRef]

160. Liu, D.; Tsau, R.; Lin, Y.; Jan, S.; Tan, F. Effect of various levels of rosemary or Chinese mahogany on the quality of fresh chicken sausage during refrigerated storage. Food Chem. 2009, 117, 106-113. [CrossRef]

161. Kharrat, N.; Salem, H.; Mrabet, A.; Aloui, F.; Triki, S.; Fendri, A.; Gargouri, Y. Synergistic effect of polysaccharides, betalain pigment and phenolic compounds of red prickly pear (Opuntia stricta) in the stabilization of salami. Int. J. Biol. Macromol. 2018, 111, 561-568. [CrossRef] [PubMed]

162. Karabagias, I.; Badeka, A.; Kontominas, M.G. Shelf life extension of lamb meat using thyme or oregano essential oils and modified atmosphere packaging. Meat Sci. 2011, 88, 109-116. [CrossRef] [PubMed]

163. Govaris, A.; Solomakos, N.; Pexara, A.; Chatzopoulou, P.S. The antimicrobial effect of oregano essential oil, nisin and their combination against Salmonella enteritidis in minced sheep meat during refrigerated storage. Int. J. Food Microbiol. 2010, 137, 175-180. [CrossRef] [PubMed]

164. Upadhyay, A.; Upadhyaya, I.; Kollanoor-Johny, A.; Baskaran, S.A.; Mooyottu, S.; Karumathil, D.; Venkitanarayanan, K. Inactivation of Listeria monocytogenes on frankfurters by plant-derived antimicrobials alone or in combination with hydrogen peroxide. Int. J. Food Microbiol. 2013, 163, 114-118. [CrossRef]

165. Xi, Y.; Sullivan, G.A.; Jackson, A.L.; Zhou, G.H.; Sebranek, J.G. Effects of natural antimicrobials on inhibition of Listeria monocytogenes and on chemical, physical and sensory attributes of naturally-cured frankfurters. Meat Sci. 2012, 90, 130-138. [CrossRef] 
166. Kurcubic, V.S.; Maskovic, P.Z.; Vujic, J.M.; Vranic, D.V.; Veskovic-Moracanin, S.M.; Okanovic, D.G.; Lilic, S.V. Antioxidant and antimicrobial activity of Kitaibelia vitifolia extract as alternative to the added nitrite in fermented dry sausage. Meat Sci. 2014, 97, 459-467. [CrossRef]

167. Chattopadhyay, R.R.; Bhattacharyya, S.K. Herbal spices as alternative antimicrobial food preservatives: An update. Pharmacogn. Rev. 2007, 1, 239-247.

168. Özvural, E.B.; Huang, Q.; Chikindas, M.L. The comparison of quality and microbiological characteristic of hamburger patties enriched with green tea extract using three techniques: Direct addition, edible coating and encapsulation. LWT Food Sci. Technol. 2016, 68, 385-390. [CrossRef]

169. Coma, V. Bioactive packaging technologies for extended shelf life of meat-based products. Meat Sci. 2008, 78, 90-103. [CrossRef]

170. Bajpai, V.K.; Baek, K.; Chul, S. Control of Salmonella in foods by using essential oils: A review. J. Food Sci. 2012, 45, 722-734. [CrossRef]

171. Ha, J.U.; Kim, Y.M.; Lee, D.S. Multilayered antimicrobial polyethylene films applied to the packaging of ground beef. Packag. Technol. Sci. 2001, 14, 55-62. [CrossRef]

172. Arcan, I.; Yemenicio, A. Incorporating phenolic compounds opens a new perspective to use zein films as flexible bioactive packaging materials. Food Res. Int. 2011, 44, 550-556. [CrossRef]

173. Widsten, P.; Mesic, P.; Cruz, C.; Fletcher, G.; Chycka, M. Inhibition of foodborne bacteria by antibacterial coatings printed onto food packaging films. J. Food Sci. Technol. 2017, 54, 2379-2386. [CrossRef] [PubMed]

174. Guarda, A.; Rubilar, J.F.; Miltz, J.; Jose, M. The antimicrobial activity of microencapsulated thymol and carvacrol. Int. J. Food Microbiol. 2011, 146, 144-150. [CrossRef] [PubMed]

175. Esfanjani, A.F.; Jafari, S.M. Biopolymer nano-particles and natural nano-carriers for nano-encapsulation of phenolic compounds. Colloids Surf. B Biointerfaces 2016, 146, 532-543. [CrossRef]

176. Donsì, F.; Annunziata, M.; Sessa, M.; Ferrari, G. Nanoencapsulation of essential oils to enhance their antimicrobial activity in foods. LWT Food Sci. Technol. 2011, 44, 1908-1914. [CrossRef]

177. Tornuk, F.; Hancer, M.; Sagdic, O.; Yetim, H. LLDPE based food packaging incorporated with nanoclays grafted with bioactive compounds to extend shelf life of some meat products. LWT Food Sci. Technol. 2015, 64, 540-546. [CrossRef]

178. Rezaei, A.; Fathi, M.; Mahdi, S. Nanoencapsulation of hydrophobic and low-soluble food bioactive compounds within di ff erent nanocarriers. Food Hydrocoll. 2019, 88, 146-162. [CrossRef]

179. Spigno, G.; Donsì, F.; Amendola, D.; Sessa, M.; Ferrari, G.; Faveri, D.M. De Nanoencapsulation systems to improve solubility and antioxidant efficiency of a grape marc extract into hazelnut paste. J. Food Eng. 2013, 114, 207-214. [CrossRef]

180. Wen, P.; Zhu, D.; Wu, H.; Zong, M.; Jing, Y. Encapsulation of cinnamon essential oil in electrospun nanofibrous film for active food packaging. Food Control 2016, 59, 366-376. [CrossRef]

181. Jayanegara, A.; Kreuzer, M.; Wina, E.; Leiber, F. Significance of phenolic compounds in tropical forages for the ruminal bypass of polyunsaturated fatty acids and the appearance of biohydrogenation intermediates as examined in vitro. Anim. Prod. Sci. 2011, 51, 1127-1136. [CrossRef]

182. Patra, A.K.; Saxena, J. Exploitation of dietary tannins to improve rumen metabolism and ruminant nutrition. J. Sci. Food Agric. 2011, 91, 24-37. [CrossRef] [PubMed]

183. Vasta, V.; Daghio, M.; Cappucci, A.; Buccioni, A.; Serra, A.; Viti, C.; Mele, M. Invited review: Plant polyphenols and rumen microbiota responsible for fatty acid biohydrogenation, fiber digestion, and methane emission: Experimental evidence and methodological approaches. J. Dairy Sci. 2019, 102, 3781-3804. [CrossRef] [PubMed]

184. Brenes, A.; Viveros, A.; Chamorro, S.; Arija, I. Use of polyphenol-rich grape by-products in monogastric nutrition. A review. Anim. Feed Sci. Technol. 2016, 211, 1-17. [CrossRef]

185. Branciari, R.; Galarini, R.; Giusepponi, D.; Trabalza-Marinucci, M.; Forte, C.; Roila, R.; Miraglia, D.; Servili, M.; Acuti, G.; Valiani, A. Oxidative status and presence of bioactive compounds in meat from chickens fed polyphenols extracted from olive oil industry waste. Sustainability 2017, 9, 1566. [CrossRef]

186. Jung, S.; Choe, J.H.; Kim, B.; Yun, H.; Kruk, Z.A.; Jo, C. Effect of dietary mixture of gallic acid and linoleic acid on antioxidative potential and quality of breast meat from broilers. Meat Sci. 2010, 86, 520-526. [CrossRef]

187. Giannenas, I.; Tzora, A.; Sarakatsianos, I.; Karamoutsios, A.; Skoufos, S.; Papaioannou, N.; Anastasiou, I.; Skoufos, I. The effectiveness of the use of oregano and laurel essential oils in chicken feeding. Ann. Anim. Sci. 2016, 16, 779-796. [CrossRef] 
188. Govaris, A.; Florou-Paneri, P.; Botsoglou, E.; Giannenas, I.; Amvrosiadis, I.; Botsoglou, N. The inhibitory potential of feed supplementation with rosemary and/or $\alpha$-tocopheryl acetate on microbial growth and lipid oxidation of turkey breast during refrigerated storage. LWT Food Sci. Technol. 2007, 40, 331-337. [CrossRef]

189. García, E.M.; López, A.; Zimerman, M.; Hernández, O.; Arroquy, J.I.; Nazareno, M.A. Enhanced oxidative stability of meat by including tannin-rich leaves of woody plants in goat diet. Asian Australas. J. Anim. Sci. 2019, 32, 1439-1447. [CrossRef]

190. Liu, H.; Zhou, D.; Tong, J.; Vaddella, V. Influence of chestnut tannins on welfare, carcass characteristics, meat quality, and lipid oxidation in rabbits under high ambient temperature. Meat Sci. 2012, 90, 164-169. [CrossRef]

191. Liu, H.; Li, K.; Mingbin, L.; Zhao, J.; Xiong, B. Effects of chestnut tannins on the meat quality, welfare, and antioxidant status of heat-stressed lambs. Meat Sci. 2016, 116, 236-242. [CrossRef] [PubMed]

192. Ranucci, D.; Beghelli, D.; Trabalza-Marinucci, M.; Branciari, R.; Forte, C.; Olivieri, O.; Badillo Pazmay, G.V.; Cavallucci, C.; Acuti, G. Dietary effects of a mix derived from oregano (Origanum vulgare L.) essential oil and sweet chestnut (Castanea sativa Mill.) wood extract on pig performance, oxidative status and pork quality traits. Meat Sci. 2015, 100, 319-326. [CrossRef] [PubMed]

193. Serrano, R.; Jordán, M.J.; Bañón, S. Use of dietary rosemary extract in ewe and lamb to extend the shelf life of raw and cooked meat. Small Rumin. Res. 2014, 116, 144-152. [CrossRef]

194. Simitzis, P.E.; Deligeorgis, S.G.; Bizelis, J.A.; Dardamani, A.; Theodosiou, I.; Fegeros, K. Effect of dietary oregano oil supplementation on lamb meat characteristics. Meat Sci. 2008, 79, 217-223. [CrossRef]

195. Luciano, G.; Vasta, V.; Monahan, F.J.; López-Andrés, P.; Biondi, L.; Lanza, M.; Priolo, A. Antioxidant status, colour stability and myoglobin resistance to oxidation of longissimus dorsi muscle from lambs fed a tannin-containing diet. Food Chem. 2011, 124, 1036-1042. [CrossRef]

196. Carocho, M.; Morales, P.; Ferreira, I.C.F.R. Reviewing the chemistry, food applications, legislation and role as preservatives. Trends Food Sci. Technol. 2018, 71, 107-120. [CrossRef]

197. European Parliament and Council Commission Regulation (EU). Amending Annex II to Regulation (EC) No 1333/2008 of the European Parliament and of the Council by establishing a Union list of food additives. Off. J. Eur. Union 2011, L295, 1-177. [CrossRef]

198. Commission Implementing Regulation (EU). Adopting the list of flavouring substances provided for by Regulation (EC) No 2232/96 of the European Parliament and of the Council, introducing it in Annex I to Regulation (EC) No 1334/2008 of the European Parliament and of the Council and repealing Commission Regulation (EC) No 1565/2000 and Commission Decision 1999/217/EC. Off. J. Eur. Union 2012, L 267, 1-161.

199. European Commission Regulation (EC). On active and intelligent materials and articles intended to come into contact with food. Off. J. Eur. Union 2009, L 135, 3-11.

200. Paibon, W.; Yimnoi, C.; Tembab, N.; Boonlue, W.; Jampachaisri, K.; Nuengchamnong, N.; Waranuch, N.; Ingkaninan, K. Comparison and evaluation of volatile oils from three different extraction methods for some Thai fragrant flowers. Int. J. Cosmet. Sci. 2011, 33, 150-156. [CrossRef]

201. Mohammadhosseini, M.; Sarker, S.D.; Akbarzadeh, A. Chemical composition of the essential oils and extracts of Achillea species and their biological activities: A review. J. Ethnopharmacol. 2017, 199, 257-315. [CrossRef] [PubMed]

202. Swamy, M.K.; Akhtar, M.S.; Sinniah, U.R. Antimicrobial properties of plant essential oils against human pathogens and their mode of action: An updated review. Evid Based Complement Alternat Med. 2016. [CrossRef] [PubMed]

203. Martins, S.; Mussatto, S.I.; Martínez-avila, G.; Montañez-saenz, J.; Aguilar, C.N.; Teixeira, J.A. Bioactive phenolic compounds: Production and extraction by solid-state fermentation. A review. Biotechnol. Adv. 2011, 29, 365-373. [CrossRef] [PubMed]

204. Zhang, W.; Xiao, S.; Samaraweera, H.; Joo, E.; Ahn, D.U. Improving functional value of meat products. Meat Sci. 2010, 86, 15-31. [CrossRef] [PubMed]

205. Toldrá, F.; Reig, M. Innovations for healthier processed meats. Trends Food Sci. Technol. 2011, $22,517-522$. [CrossRef]

206. Olmedilla-Alonso, B.; Jiménez-Colmenero, F.; Sánchez-Muniz, F.J. Development and assessment of healthy properties of meat and meat products designed as functional foods. Meat Sci. 2013, 95, 919-930. [CrossRef] [PubMed] 
207. Abdallah, A.; Zhang, P.; Elemba, E.; Zhong, Q.; Sun, Z. Carcass characteristics, meat quality, and functional compound deposition in sheep fed diets supplemented with Astragalus membranaceus by-product. Anim. Feed Sci. Technol. 2019, 259, 114346. [CrossRef]

208. Pogorzelska-Nowicka, E.; Atanasov, A.G.; Horbanczuk, J.; Wierzbicka, A. Bioactive compounds in functional meat products. Molecules 2018, 23, 307. [CrossRef]

209. Ono, Y.; Hattori, E.; Fukaya, Y.; Imai, S.; Ohizumi, Y. Anti-obesity effect of Nelumbo nucifera leaves extract in mice and rats. J. Ethnopharmacol. 2006, 106, 238-244. [CrossRef]

210. Jeong, C.H.; Choi, G.N.; Kim, J.H.; Kwak, J.H.; Jeong, H.R.; Kim, D.O.; Heo, H.J. Protective effects of aqueous extract from Cudrania tricuspidata on oxidative stress-induced neurotoxicity. Food Sci. Biotechnol. 2010, 19, 1113-1117. [CrossRef]

211. Lin, D.; Xiao, M.; Zhao, J.; Li, Z.; Xing, B.; Li, X.; Kong, M.; Li, L.; Zhang, Q.; Liu, Y.; et al. An overview of plant phenolic compounds and their importance in human nutrition and management of type 2 diabetes. Molecules 2016, 21, 1374. [CrossRef] [PubMed]

212. Chakroun, M.; Khemakhem, B.; Ben Mabrouk, H.; El Abed, H.; Makni, M.; Bouaziz, M.; Drira, N.; Marrakchi, N.; Mejdoub, H. Evaluation of anti-diabetic and anti-tumoral activities of bioactive compounds from Phoenix dactylifera L.'s leaf: In vitro and in vivo approach. Biomed. Pharmacother. 2016, 84, 415-422. [CrossRef] [PubMed]

213. Kchaou, W.; Abbès, F.; Ben Mansour, R.; Blecker, C.; Attia, H.; Besbes, S. Phenolic profile, antibacterial and cytotoxic properties of second grade date extract from Tunisian cultivars (Phoenix dactylifera L.). Food Chem. 2016, 194, 1048-1055. [CrossRef] [PubMed]

(C) 2020 by the authors. Licensee MDPI, Basel, Switzerland. This article is an open access article distributed under the terms and conditions of the Creative Commons Attribution (CC BY) license (http://creativecommons.org/licenses/by/4.0/). 